\title{
VALENTÍA, FEMINISMO Y RESILIENCIA. LA (IN)VISIBILIDAD DE LA MUJER MUSULMANA A TRAVÉS DEL CINE
}

\author{
Actual / Courage, Feminism and Resilience. \\ The (In)Visibility of the Muslim Woman through Contemporary Cinema
}

\author{
Igor Barrenetxea Marañón \\ ibm@bezeroak.euskaltel.es \\ Universidad Internacional de La Rioja. España
}

Fecha de recepción: 16/11/2019

Fecha de aceptación: 23/03/2020

Resumen: El cine es una ventana abierta al mundo que nos rodea. Las diferentes cinematografías nos acercan y revelan, al mismo tiempo, preocupaciones y realidades sociales de muy diversa naturaleza. En este caso, esta investigación se centra en analizar a través de una serie de filmes seleccionados las diferencias problemáticas de la mujer musulmana (sus padecimientos en las guerras, indefensión, pérdida de derechos y libertades, acoso, abusos, resiliencia, etc.) en diferentes países y entornos. Cada una de estas producciones desvela un universo femenino con una intención muy importante y crucial: sensibilizarnos y alterar las inercias sociales que se dan en muchos países. El cine se convierte, así, en una palanca de cambio histórico que no solo hace visible a la mujer (al mostrar su sufrimiento), sino que se adentra, además, en recalcar su imprescindible protagonismo en todos los órdenes de la vida y la importancia que cobra la educación a la hora de materializar su empoderamiento.

Palabras clave: Mujer musulmana; Cine; Historia; Feminismo; Visibilidad.

Abstract: Cinema is an open window to the world around us. The different cinematographies get us close to and, at the same time, reveal for us highly diverse concerns and social realities. In this case, our investigation focuses on analysing the varied difficulties of the Muslim woman (their suffering in wars, defencelessness, loss of rights and freedom, harassment, abuse, resilience, etc.) in different countries and environments, through a series of selected films. Each and every one of these films gets into disclosing a feminine universe with a very important and crucial purpose: to raise awareness and alter the social inertia taking place in many countries. Cinema becomes, thus, a lever to historical change which, not only makes women visible (by showing their suffering), but also goes deep into 
stressing their essential prominence in all areas of life and the importance that education gains when bringing to life their own empowerment.

Keywords: Muslim woman; Cinema; History; Feminism; Visibility.

SUMARIO: 1. Introducción. 2. La situación de la mujer musulmana. 3. Retratos de mujeres en el cine. 3.1. Líbano: ¿Y ahora adónde vamos? (2011), de Nadine Labaki. 3.2. Palestina: Los limoneros (2008), de Eran Riklis. 3.3. Afganistán (I): Buda estalló por vergüenza (2007), de Hana Makhmalbaf. 3.4. Afganistán (II): La piedra de la paciencia (2012), de Atiq Rahimi. 3.5. Arabia Saudí: La bicicleta verde (2012), de Haifaa Al Mansour. 3.6. Irán: Persépolis (2007), de Marjane Satrapi y Vincent Paronnaud. 3.7. Turquía: La fuente de las mujeres (2011), de Radu Mihaileanu. 3.8. Yemen: 10 años y divorciada (2014), de Khadija Al-Salami. 3.9. Egipto: El Cairo 678 (2010), de Mohamed Diab. 4. Cuadro síntesis ideas principales. 5. A modo de conclusión. 6. Referencias bibliográficas.

"El feminismo islámico tiene como objetivo recuperar la idea de la umma, o comunidad islámica concebida como un espacio compartido - compartido igualmente por mujeres y hombres - y como una comunidad global pluralista.

(Badran, 2010, p. 70).

\section{INTRODUCCIÓN}

No hay duda de que todas las personas buscamos nuestro sitio en este mundo. Pero vivimos condicionados por el contexto en donde nacemos y crecemos.

$Y$, sin embargo, más que ninguna otra cuestión, hay un aspecto que marca, o ha marcado, la distinción humana: nacer hombre o mujer. Es evidente que la biología nos ha hecho diferentes, pero no distintos a la hora de querer vivir satisfactoriamente, con la garantía de poder acceder y tener posibilidad de optar a una serie de oportunidades vitales y, sobre todo, a ser tratados con la misma dignidad.

Claro que las sociedades no son todas iguales, los grupos humanos son muy diversos y complejos, el planeta se divide en fronteras geográficas naturales y otras artificiales. Y, así mismo, se producen conflictos que afectan a ciertos lugares de una forma catastrófica.

Ahora bien, centrándonos en los aspectos del género, la dura realidad es que el hecho de haber nacido de un sexo $u$ otro determina parte de lo que somos.

La pugna por la igualdad, no por el paternalismo, por el mutuo reconocimiento como iguales, es una batalla que todavía se está librando, los prejuicios, el tradicionalismo, la costumbre, las viejas mentalidades y los arcaísmos que son tan difíciles de erradicar están muy presentes, tanto en culturas menos desarrolladas como en las desarrolladas. No hay igualdad.

En el marco de tal diversidad de situaciones y problemáticas que se dan (desde la ablación a la poligamia, pasando por el maltrato, el uso del velo o la imposición 
de la sharía), esta investigación se centra, en esencia, en la mujer musulmana (Fernández Guerrero, 2011, pp. 267-286); en su papel en las sociedades árabes-musulmanas tomando como ejemplos varios filmes de enorme interés que radiografían parte de las injusticias que soportan y que modelan, así mismo, una clase de mujer visible que sufre, padece $y$, ante todo, es más consciente de lo que se piensa, o considera, de las cadenas que las atan a ciertos convencionalismos, subordinándolas al hombre. También se abordará su papel en los conflictos, puesto que ellas mismas se ven afectadas (Magallón, 2017, pp. 15-33) ${ }^{1}$.

Así que este artículo pretende, por un lado, realizar una breve síntesis sobre algunos de los problemas que viven y padecen las mujeres en este marco geográfico $y$, por otro, mostrar como el cine es capaz de desvelar y denunciar parte de estas realidades, en algunos casos, vistas por ellas mismas como directoras de prestigio. Filmes como ¿Y ahora adónde vamos? (2011), de Nadine Labaki, sobre el papel activo que pueden tener las mujeres en los conflictos (pacifismo); Los limoneros (2008), de Eran Riklis, presenta el sufrimiento de las féminas palestinas; Buda estalló por vergüenza (2007), de Hana Makhmalbaf, sobre la situación de la infancia en Afganistán y el valor de la educación; La piedra de la paciencia (2014), de Atiq Rahimi, que descubre la psicología femenina y sus desvelos; La bicicleta verde (2012), de Haifaa Al Mansour, retrato de la situación de la mujer en Arabia Saudí; Persépolis (2007), de Marjane Satrapi y Vincent Paronnaud, sobre las experiencias de una niña a lo largo del tiempo en Irán desde la época del Sah a la Revolución islamista; La fuente de las mujeres (2011), de Radu Mihaileanu, muy reveladora sobre la importancia de atender los problemas básicos de las mujeres; 10 años y divorciada (2014), de Khadija Al-Salami, duro alegato contra los matrimonios infantiles en Yemen; $y$, finalmente, El Cairo 678 (2010), de Mohamed Diab, sobre el acoso sexual en Egipto, son todos ellos logrados ejemplos.

Tal muestra de películas es muy ilustrativa de inquietudes y situaciones que nos permiten comprender 0 , al menos, acercarnos a una realidad marcada por la injusticia, el amargor, la dureza y la arbitrariedad. E inciden no solo en los padecimientos y crueldades que sufren sino también en la capacidad de las mujeres de resistir, aguantar, superar y dar soluciones. Y así, nos presentan a unas mujeres dentro de una feminidad que ya no "es sinónimo de debilidad, ingenuidad, abnegación y resignación», frente al modelo de hombre que se propone con «fuerza, determinación, iniciativa y valentía» (El Saadawi, 2017, p. 197).

El cine, sin duda, es un vehículo muy interesante a la hora de desvelar de forma muy clara, reivindicativa y rotunda los problemas tan diversos que las aquejan, y de denunciar los prejuicios y arcaísmos imperantes, así como su valentía a la hora de enfrentarse a ellos. La imagen no solo nos permite observar tales sociedades y

${ }^{1}$ El movimiento pacifista femenino se consagró en 1915, entre el 28 de abril y el 1 de mayo, en el Congreso Internacional de Mujeres, en la Haya. 
acercarnos a ellas para no percibirlas como extrañas o ajenas a nosotros (Pozas Pardo y Macías, 2007, p. 16), sino para conocer cómo se retratan a sí mismas (de lo que se desvela de ellas, pero también de lo que se oculta o no se habla, igual de relevante), y, por descontado, como es su intención, se puede convertir en una «agente de la Historia» (Ferro, 1995, p. 17) para cambiar las conciencias. Por todo ello, la metodología que se va a utilizar es la de los estudios de historia y cine, analizando el contexto general de los filmes (la mujer en el mundo musulmán) y las imágenes como documentos y fuentes de la historia (Ferro, 1995; Sorlin, 1996; Sand, 2005; y Rosenstone, 2014).

\section{LA SITUACIÓN DE LA MUJER MUSULMANA}

La realidad es que todavía no se puede afirmar sin ningún género de dudas que la igualdad entre hombres y mujeres y mujeres y hombres se ha conseguido en las sociedades. Y aun cuando la igualdad jurídica es real en muchos países, lo cierto es que todavía se dan situaciones en las que la mujer sigue siendo maltratada, violentada o discriminada (Van Der Gaag, 2005; Mestre i Mestre, 2008; Maquieira, 2010).

Es una batalla que está muy presente en los medios de comunicación. Sin embargo, en las sociedades islámicas, donde muchas todavía no han conseguido establecer unos regímenes democráticos adecuados, su situación es más problemática y su indefensión mayor.

En primer lugar, por una cuestión social. A pesar de que el islam es una religión igualitaria, hay una serie de actitudes y normas no escritas restrictivas y muy tradicionales que subordinan la mujer al hombre de forma muy rígida. En segundo lugar, son sociedades tremendamente arcaicas por lo que el papel de la mujer como esposa y madre lastra sus posibilidades de independencia y alcance de logros personales. En tercer lugar, su status jurídico de igualdad no está ni mucho menos aceptado o ya, de existir, no se aplica ni desarrolla ni se vigila su cumplimiento. En cuarto lugar, está la fuerte presencia, actividad e influencia de grupos yihadistas que pretenden imponer una visión medieval y arcaizante (Abumalham, 1999, pp. 143-145; Badran, 2012, pp. 35-336; Terrón Caro, 2012, p. 240).

$\mathrm{Y}$, finalmente, en el mismo orden de importancia, se encuentran los conflictos y las tensiones sociales internas tan activos en muchos de tales países, donde niños y ancianos son los grupos que más sufren en carne propia la cruda realidad de la violencia. Si tomamos como modelo a una de las sociedades más impermeables al cambio social como es Arabia Saudí, hemos de considerar que hasta 2015 no se le concedió a la mujer el derecho al voto, y, aun con todo, debe acudir a colegios electorales segregados y su presencia en el parlamento o en puestos de responsabilidad es escasa. Otro dato que ejemplifica su situación es que hasta 2017, y no sin mucha polémica y crítica religiosa, no se les permitió conducir, dependiendo de los 
hombres por completo para poder desplazarse o salir de sus hogares libremente (Carrión, 2017).

Es más, en 2014, Arabia Saudí anunciaba un plan para desplazar a las mujeres de la zona cerca de la Kaaba, en La Meca, y trasladarlas más lejos por falta de espacio. Inmediatamente se produjo una protesta mundial porque eso discriminaba abiertamente a las mujeres. El proyecto se tuvo que aparcar por las fuertes presiones internacionales recibidas, pero no deja de ser un símbolo muy recurrente de cómo los sectores más integristas encajan a la mujer en el islam (Badran, 2010, p. 83).

En países más modernos, como Turquía, todavía hay amplias zonas en donde la mujer está seriamente discriminada y es maltratada, sin libertad para elegir, por ejemplo, con quién quiere casarse. $Y$, en los últimos años, han visto como sus derechos han sido restringidos (Arabaci, 2018, pp. 91-102).

En los territorios palestinos, la mujer está al albur de un conflicto que le deja profundas huellas, debiendo casarse pronto y tener hijos muy joven, sin poder optar a un futuro diferente al de convertirse en madre. Por supuesto, no olvidemos que hay sociedades en donde no puede verse el rostro de la mujer en público o donde temas como la sexualidad (la ablación ${ }^{2}$ o las relaciones extramatrimoniales) o la concepción (el aborto o los anticonceptivos) son tabú o, incluso, considerados como graves crímenes penados con suma dureza (Kayaní y Zein, 2002, pp. 55-66). Además de los tristemente conocidos como crímenes de honor, en los que «el cuerpo de la mujer se ha convertido en el lugar donde recae la represión y ocurre la discordia» (El Saadawi, 2017, p. 22).

Aunque, en términos generales, cada vez hay un mayor acceso a la enseñanza tanto media como superior, todavía su situación en el terreno del campo laboral es muy precaria. Tampoco hay muchas mujeres que accedan a puestos de responsabilidad o a cargos públicos (y suele incluso estar mal visto) y el acceso a la enseñanza superior está muy restringido (Terrón Caro, 2012, pp. 237-254; Zurbano Berenguer, 2012). Sin embargo, no debemos pensar que la lucha por la igualdad es nueva, importantes movimientos feministas ya se dieron en Egipto en 1920, y hubo escritores que ya marcaron ciertas tendencias, aunque, desgraciadamente, no consiguieron afianzarse (Pérez Álvarez y Rebollos Avalos, 2009; Badran, 2010, p. 73; El Saadawi, 2017, pp. 355-356) $)^{3}$.

${ }^{2}$ A pesar de los intentos por evitar estas prácticas preislámicas, todavía muchos países las consideran lícitas y está muy arraigada dicha costumbre en las poblaciones.

${ }^{3}$ En Egipto, fue la Unión feminista árabe (1919), la Liga de mujeres del Líbano (1943), en Marruecos el Partido Unión Nacional de Fuerzas Populares o en Túnez la Unión Nacional de Mujeres Tunecinas (1955). Si bien, en 1855, se publicó el libro Las piernas cruzadas, de Ahmed Faris al-Schidyac, que se considera una de las primeras publicaciones en favor de la emancipación de la mujer musulmana, al que siguieron otros escritos. 
En todo caso, ese proceso reivindicativo ha cobrado una mayor visibilidad, ya sea por ese empoderamiento femenino paulatino que se ha ido dando a todos los niveles (cultural, social y político), a pesar de las fuertes resistencias que se han producido, ya porque ellas mismas han ocupado su lugar y espacio, a pesar de tales adversidades. Pero todavía la conquista definitiva y consolidación de tales derechos se torna una lucha a largo plazo debido a las diferentes situaciones, de la condición de la mujer, que se dan en el mundo. Con todo, el cine, como ya se ha señalado, se ha convertido en uno de los mejores instrumentos de expresión, reivindicación, concienciación y dignificación para lograr cambiar el signo de los tiempos y favorecer el respeto y la igualdad entre sexos.

En este caso, la centralidad corre a cargo de la mujer musulmana, pero no deja de ser un referente universal.

\section{RETRATOS DE MUJERES EN EL CINE}

\subsection{Líbano: ¿Y ahora adónde vamos? (2011), de Nadine Labaki ${ }^{4}$}

El país de los cedros ha vivido a lo largo de los años 70 y 90 desgarradoras guerras civiles ${ }^{5}$. Todavía, en la actualidad, su diversidad religiosa y étnica deriva en tensiones políticas que han llevado a puntuales enfrentamientos armados (Kassir, 1994; Corm, 2006, pp. 19-23; Ruíz, 2012, pp. 48-50) ${ }^{6}$. Es por ello que, en una entrevista, la directora del filme en cuestión, oriunda de Baabdat (Líbano), señalara: "Siento que tengo una misión, una responsabilidad, y el cine es el arma de guerra no violenta más eficaz para cambiar las cosas. Soy cineasta gracias a Líbano» (García, 2012). Labaki dejaba muy claras sus intenciones, es evidente que el conflicto libanés ha determinado, en buena medida, la producción cinematográfica, abogando por buscar fórmulas de entendimiento entre contrarios (alteridad) y por el pacifismo (Zaccak, 1997; Khatib, 2008; Hotait Salas, 2013, p. 317). Así mismo, esta militancia la ha llevado a denunciar la situación de la mujer y la historia de su país y a un marcado activismo político que la empujó a encabezar la plataforma Beirut

${ }^{4}$ Líbano, 2011. Dirección: Nadine Labaki. Guion: Nadine Labaki. Música: Khaled Mouzannar. Fotografía: Christophe Offenstein. Intérpretes: Nadine Labaki, Kevin Abboud, Claude Baz Moussawbaa, Julian Farhat, Ali Haidar, Leyla Hakim. Duración: 100 min. Premios: Mejor película en el Festival de Toronto y mejor película extranjera en Critics Choice Awards.

${ }^{5}$ Se calcula que causó entre 130000 y 250000 víctimas mortales, un millón de libaneses tuvo graves secuelas y otro millón huyó del país.

${ }^{6}$ La diversidad étnica-religiosa es muy amplia. Consta de: musulmanes (sunitas, chiitas, ismaelíes y alauís), cristianos (manoritas, católicos, ortodoxos y griegos, católicos armenios, gregorianos, ortodoxos sirios, jocobitas, nestorianos, caldeos, coptos, católicos evangélicos y católicos romanos), además de drusos y judíos. 
Medinati (Beirut nuestra ciudad), que encarna el hartazgo contra la vieja clase dirigente (Cabello Rodríguez, 2016, p. 146).

La trama de la película se ambienta en una localidad libanesa cualquiera. En ella conviven en armonía, con sus idiosincrasias locales, dos comunidades religiosas, la cristiana y la musulmana. Se respetan, pero no se mezclan. Así, Amelé, la protagonista (la propia directora), cristiana que regenta el bar del pueblo, ama en secreto a Rabih, musulmán, pero debido a sus diferentes creencias no son capaces abiertamente de expresar lo que sienten el uno por el otro, revelando que, a pesar de todo, la religión separa a las personas. Hasta que un buen día llegan noticias de enfrentamientos religiosos.

La comunidad, hasta entonces, ha vivido pacíficamente. Cada cual honra a su Dios y a sus muertos. Beben juntos en el mismo bar y también se reúnen, como si fuese una fiesta, para disfrutar y compartir en común la única televisión del pueblo, tras lograr una antena para el aparato. Es, ante todo, un pequeño universo el que se nos muestra con sus simpatías, amoríos y disputas, pero todo ello en un orden de tolerancia y respeto.

Quedan, eso sí, latentes las huellas inequívocas de un conflicto anterior, una zona minada por la que deben pasar con cautela para acceder al puente afectado por las bombas, que es el que les une con el mundo exterior. $Y$ mientras las mujeres (Takla, Rita, Afaf o Amele) son las que se encargan de realizar las tareas cotidianas, incluso de velar por los difuntos, los hombres se dedican a pasar las tardes, sin mucho que hacer. No deja de ser una comunidad con sus muestras de solidaridad, compromiso y chanzas, etc. Tal y como incide el historiador Corm, y como se muestra en la puesta en escena, "los libaneses, por muy críticos que sean de su existencia colectiva, nacional, estatal y social, están orgullosos de pertenecer a su tierra» (Corm, 2006, p. 29).

Pero esta imagen sencilla y apacible esconde tras de sí recelos y rencores que van a ser activados. El clima se enrarece en el momento en que el noticiario televisivo anuncia disturbios sectarios. El intento de las mujeres por evitar que los hombres escuchen y sepan lo que sucede fuera deriva en una suerte de acontecimientos tragicómicos. Puesto que ellas, independientemente del credo que profesan, deciden una noche romper los altavoces de la televisión y esconder la radio para que las noticias no se filtren en la localidad, con tan mala suerte que, cuando uno de los chicos decide subsanar el destrozo cogiendo un altavoz de la iglesia cristiana, rompe una cruz. Y eso hace pensar a los cristianos que ha sido un ataque de los musulmanes. Estos, a su vez, se ven agraviados cuando alguien, por un descuido, deja la puerta abierta de la mezquita y entran animales en ella, lo que hace que, sin pensarlo, culpen a los cristianos.

Este y otros incidentes (como la muerte de Hassan de forma accidental por una bala perdida) llevan a la máxima tensión a las dos comunidades religiosas, a pesar de la llamada a la paz del imán y del sacerdote. Y ante la conflictividad que empieza 
a reinar, las mujeres, viendo que la situación se les está yendo de las manos (incluso pergeñan un milagro), deciden desviar la atención de los hombres contratando a un grupo de variedades compuesto por bailarinas extranjeras y exóticas, para evitar la confrontación. La fiesta, en la que reúnen a todos los hombres, a pesar del clima belicista existente, les permite a las mujeres poner ese mundo del revés y muestra su soberbio ingenio (tanto de las cristianas como de las musulmanas) por evitar un nuevo enfrentamiento, conocedoras del dolor que causan. Y cuando los hombres se despiertan de su borrachera (han sido convenientemente drogados) se encuentran con algo inesperado: sus mujeres han cambiado de religión...

En off, al cierre de la misma, se señalan de forma muy hábil las intenciones de la directora: "He contado mi historia a los que la habéis escuchado. La historia de un pueblo que encontró la paz cuando a su alrededor reinaba la violencia. De unos hombres que tuvieron un sueño tan profundo que al despertar ya no encontraron la guerra. De unas mujeres vestidas de negro que lucharon con flores y plegarias en vez de armas y bengalas. $Y$ para proteger a sus hijos se hicieron con su propio destino para encontrar un nuevo camino...».

La escena final es muy sutil y hábil ya que nos lleva, de nuevo, al cementerio que hay a las afueras del pueblo. Al principio, hemos visto como las mujeres, de riguroso luto, iban depositando flores a sus seres queridos con un sentimiento desgarrado. Una parte está dedicada a los difuntos cristianos y otra a los musulmanes, caídos en las guerras del pasado. Pero en esta ocasión, tras lo sucedido, los hombres que portan el féretro de Hasim no saben qué hacer, ¿dónde enterrar al difunto? Con humor negro desvela lo absurdo de estos odios que acaban en el mismo lugar, sin que haya una diferencia entre unos y otros muertos (Luján Ramos, 2014, pp. 149-162).

La directora libanesa se adentró por un territorio complejo, simplificando muchos aspectos de la realidad de su propio país, pero ofreciéndonos en ellos unos detalles nada manidos ni superficiales, sino una clara y contundente mirada feminista.

La lección tiene un mensaje doble: los conflictos surgen de la manera más tonta (o incidental) y el papel de las mujeres es fundamental a la hora de buscar una manera de entenderse (pues las sociedades o los integrantes de las comunidades no son tan distintos). O lo contrario, si se deja la resolución de los conflictos en manos de los hombres solo hay dolor y sufrimiento.

Con ingenio, humor y una hábil manera de desdramatizar la violencia de su país, nos presenta una bella metáfora sobre cómo las féminas, con sutileza, son capaces de resolver y encarar los agravios que los hombres generan. No hay realidad virulenta que no pueda ser sosegada; no hay conflicto que no pueda ser apaciguado con la terquedad de saber que los efectos son todavía muchos más desgarradores y nefastos. Es un alegato de alteridad y pacifismo, en el que el otro, sin duda alguna, no es muy distinto del nosotros. Es, por todo, una virtuosa lección de tolerancia, respeto y entendimiento interreligioso, en el que el cine cobra una dimensión didáctica muy viva, en un país donde el desgarro por la violencia ha sido tan fuerte y tan presente. 


\subsection{Palestina: Los limoneros (2008), de Eran Riklis}

La realidad en los territorios palestinos ha venido ensombrecida por el conflicto árabe-israelí, surgido con la constitución del Estado de Israel en 1948. Desde entonces, ese marco se ha convertido en una permanente herida abierta, señalada por incesantes guerras y una inestabilidad latente, que no ha acabado de solventarse ni con el reconocimiento de los territorios bajo el gobierno de la Autoridad Nacional Palestina (ANP) ni como Estado Observador de la ONU.

Aún, en la actualidad, la difícil convivencia entre palestinos e israelíes, marcada por enfrentamientos en la Franja de Gaza, Jerusalén o Cisjordania está a la orden del día (Finkelstein, 2003; Solar, 2002; Quigley, 2005; Culla, 2005).

Han sido innumerables los filmes, desde el punto de vista israelí o palestino, que han retratado la cuestión, aunque más bien pocos se han atrevido a abordarla desde el punto de vista femenino, como es el caso que nos ocupa (Barrenetxea, 2014). Lo interesante del caso reside en que el encargado de llevar a buen puerto Los limoneros es un reputado cineasta israelí que se inspiró en un hecho real, aunque con sus licencias, para pergeñar el guion del largometraje (Vicente, 2008).

La trama versa sobre la historia de Salma cuyo terreno de limoneros, en Cisjordania, colinda con la frontera con Israel. Un buen día escucha ruidos extraños afuera. En la casa de enfrente se ha instalado a vivir el ministro de Defensa israelí, Israel, con su mujer, Mira, y están desplegando una serie de medidas de vigilancia. Todo ello no debería afectar a Salma, hasta que el servicio de seguridad teme que el apacible terreno arbolado represente una amenaza, ante la posibilidad de que se puedan esconder posibles terroristas que lleven a atentar contra la vida del ministro. Y deciden talar los limoneros. Esta inesperada realidad hace que la vida de Salma dé un vuelco repentino. Necesita defender sus derechos ante la justicia militar israelí, pero es una mujer viuda, indefensa y el único hijo (emigrado en EE. UU. para poder estudiar) que tiene no siente ningún apego hacia unos limoneros que han pertenecido a la familia desde siempre.

El litigio de la viuda contra las autoridades israelíes muestra la realidad cruda y áspera de una vecindad entre palestinos e israelíes vertebrada por la desconfianza y la amenaza. El temor a un atentado configura parte de un imaginario de guerra, que se exagera hasta el límite de que unos simples árboles acaban por convertirse en una amenaza nacional... Así mismo, la sensación de impotencia de Salma, atrapada por la arbitrariedad israelí y por la incomprensión y utilización de

7 Israel, 2008. Título original: Etz Limon. Dirección: Eran Riklis. Fotografía: Rainer Klausmann. Guion: Eran Riklis y Suha Arraf. Montaje: Tova Asher. Música: Habib Shadah. Sonido: As Milo, Emil Klotzsch, Gil Toren, Hervé Buirette, Roland Platz. Vestuario: Rona Doron. Reparto: Hiam Abbass, Doron Tavory, Ali Suliman, Rona Lipaz-Michael y Tarik Kopty. Duración: 106 min. Premio del Público en el Festival de Berlín 2008.

${ }^{8}$ Aunque los árboles en litigio, en verdad, eran unos olivos. 
su reclamación, para convertirla en símbolo de la causa palestina, clarifica su doble victimismo. Pues cuando acude para recabar consejo y apoyo de la comunidad palestina, el patriarca, Abu Kamal, le indica, para desconsuelo de Salma, que no puede aceptar ninguna indemnización por parte de Israel, pero tampoco le ofrece ninguna ayuda. Como explica Culla (2005, p. 281), «por descontado, la intransigencia y el dogmatismo no son patrimonio de un solo bando». Salma, a pesar de todo, no se resignará y contratará a un joven y ambicioso abogado, Ziad, que aprovechará la circunstancia para servirse del litigio y convertirlo en una bandera en defensa de la causa palestina a nivel internacional y granjearse un nombre en el seno de la Autoridad Palestina. Todo ello más por interés personal que por, verdaderamente, defender a la viuda.

La hondura del mensaje de acabar con esos muros visibles e invisibles de prejuicios e intransigencia se ve reforzada, al mismo tiempo, por el cambio de actitud y la comprensión de la situación de Mira, la mujer del ministro, quien se convierte en otra víctima indirecta. A pesar de que es israelí, va a sentir compasión por la injusticia que se está cometiendo con Salma, viendo como la incomprensión no solo afecta a la convivencia o a la paz, sino a personas corrientes que se encuentran entre los dos fuegos. Hipocresías políticas y sociales (el ministro no duda en afirmar que los árboles son sagrados, aunque luego le parece bien talar los de Salma), se unen así para configurar un universo en el que la parte más débil es la que más sufre.

A la vista está que Riklis no pretende debatir ni plantear una solución sobre el conflicto palestino-israelí, sino mostrar el lado humano del problema que afecta a todos, de maneras distintas, eso sí, en especial a las mujeres (de ambos bandos, aunque sea la palestina la que se lleve la peor parte). Así mismo, también nos muestra el fuerte contraste (de desarrollo y expectativas) entre estos dos mundos tan opuestos entre sí, a pesar de que son fronterizos (la parte israelí es mucho más moderna que la palestina). Y pone el acento en que lo que verdaderamente está en juego no es una causa sino la deshumanización, tanto del otro como de uno mismo. Se aleja, así, el director de ese cine hebreo nacionalista anterior de perspectiva «heroico e idealista» (Pappé, 2015, pp. 73-85), para ofrecernos otro de una dimensión emocional sobrecogedora.

Frente al mensaje del filme de Labaki, en Los limoneros, la mujer [musulmana], a pesar de su situación, se enfrenta a una realidad dominada por los hombres, de forma estoica y valiente. Es evidente que no puede vencer, pero tampoco se resignará. Esta resiliencia dice mucho de ella y lanza, por lo tanto, un mensaje amargo, pero no necesariamente negativo, para activar la conciencia de cara a tender un puente entre dos sociedades tan cercanas y lejanas al tiempo, sobre un conflicto histórico que solo trae consigo dolor, amargor y sufrimiento. 


\subsection{Afganistán (I): Buda estalló por vergüenza (2007), de Hana Makhmalbaf ${ }^{9}$}

"La historia reciente de Afganistán ha sido, sin duda, dramática y las perspectivas a medio plazo para el país tampoco son muy halagüeñas» $(2017$, p. 21), sintetiza Castien. Sin duda, el devenir de la historia del país, marcado por su inestabilidad interna y, posteriormente, por la invasión de la URSS (1979), ha servido para visibilizar de una forma muy recurrente a la mujer musulmana debido, sobre todo, a buscar en ello la excusa para proceder contra el denostado régimen Talibán, tras el 11-S. Sin embargo, hay que pensar que la situación de las mujeres afganas es la punta del iceberg de una realidad mucho más amarga (Griffin, 2001; Rashid, 2001, Cooley, 2002; Gomà, 2011).

En este caso, la joven directora iraní Hana Makhmalbaf, hija de los realizadores Mohsen Makhmalbbaf (Archive) ${ }^{10}$ y Marziyeh Meshkini, con tan solo 18 años llevaría a cabo una de las más soberbias, amargas y duras miradas sobre la sociedad afgana a través de los ojos de una niña de 6 años, y sería recibida de forma entusiasta y acumularía infinidad de premios internacionales ${ }^{11}$.

Rodada en escenarios naturales, el valle de Bamiyan, donde los talibanes volaron los milenarios budas excavados en la roca (Morales Fajardo, Mejía López y Galeana Estrada, 2017, p. 41) ${ }^{12}$, nos presenta a Bakhtay, una niña cuyo gran afán es asistir a la escuela local para que le cuenten historias divertidas, igual que la que ha aprendido su vecino, un niño un poco mayor que ella, Abbas. Sin embargo, no lo va a tener nada fácil.

${ }^{9}$ Irán-Francia, 2007. Título original: Buda as Sharm foru rikht. Dirección: Hana Makhmalbaf. Guión: Marzieh Meshkini. Producción: Makhmalbaf Film House, Wild Bunch. Música: Tolibhon Shakhidi. Fotografía: Ostad Ali. Montaje: Mastaneh Mohajer. Interpretación: Nikbakth Noruz (Bakhtay), Abodlali Hoseinali (el Talibán), Abbas Alijote (Abbas). Duración: 81 minutos.

${ }^{10}$ Director, escritor, guionista, productor de cine y activista a favor de los derechos humanos. En su haber tiene películas como: El vendedor ambulante (1986), El ciclista (1987), Un momento de inocencia (1995), Kandahar (2001) o El grito de las hormigas (2005), entre otros.

${ }^{11}$ Premio especial del jurado, Festival Internacional de San Sebastián, España, 2007; Premio Unicef Paolo Ungari, Festival Internacional de Roma, Italia, 2007; Premio Daniel Langlois a la Innovación, Festival du nouveau cinéma, Montréal, Canadá, 2007; Premio Woman \& Equality, Festival de Salónica, Grecia, 2007; Oso de cristal y premio por la paz, Festival Internacional de Berlín, Alemania, 2008; Premio Finestre sul Mondo a la mejor película, Festival de cine africano, de Asia y América Latina, Milán, Italia, 2008; Premio FIPRESCI a la mejor película, Festival Internacional de cine de mujeres, Ankara, Turquía, 2008; Premio del Traverse City Film Festival, Estados Unidos, 2008; Premio del jurado, Festival internacional de cine de autor, Marruecos, 2008; Silver Mirror, Festival de cine del sur, Noruega, 2008 y el Golden Deer, Festival de Molodist, Ukrania, 2008, entre otros.

12 Los dos Budas eran dos figuras monumentales, de 55 y 38 metros de altura cada una, construidos en los siglos $v$ y vi, tallados al borde de un acantilado y declarados Patrimonio de la Humanidad por la Unesco. 
Vive en las cuevas, y debe encargarse de cuidar de su hermanito, al que ata para que no se escape, y para poder agenciarse un cuaderno y un lápiz ha de pasar por una serie de vicisitudes. Pero cuando, por fin, llega a la escuela, con el cuaderno y un pintalabios como material de escritura, no es bien recibida ni aceptada por sus compañeras ni por su maestra. Las aventuras y desventuras de la niña, sola, en un mundo adulto que no la hace caso, y un universo infantil hostil, se convierten, a la postre, en una recurrente metáfora de la historia del país en los últimos años. En el transcurso de su trayecto hacia la escuela, se encuentra con una partida de niños que juegan a ser talibanes. No dudan en mostrarse duros e inclementes con ella, y con otras niñas, que han retenido en una cueva cercana por ser unas "pecadoras».

Incluso, en esos roles que asumen, escenifican la lapidación de Bakhtay, que parece que van a hacerlo en serio. Más tarde, se harán pasar por soldados americanos y acosarán de nuevo a la pobre niña, al considerar que es una «terrorista», mostrando, una vez más, los traumas y desvelos que los niños han incorporado a sus juegos, actuando como si fueran de verdad.

La tersa y cuasi documental experiencia de Bakhtay es sobrecogedora.

El desgarrador relato describe una realidad áspera y amarga, mísera, mayormente, en la que lo que más llama la atención es la precaria escolarización (la mayoría de los centros son al aire libre, de escasos medios) y la falta de cercanía con una infancia que ha visto como guerra tras guerra sus vidas han sido marcadas irremediablemente por la violencia, el fanatismo y el horror. Y, por supuesto, radiografía la condición y situación de la mujer que ha quedado hundida bajo el enorme peso del tradicionalismo, del integrismo religioso y la falta de desarrollo.

En 2001, por ejemplo, año de la derrota parcial de los talibanes, en el Índice de Pobreza Humana, elaborado por la ONU, Afganistán se encontraba en el puesto 89 del total de 90 países en desarrollo analizados (Hdr, 155).

El informe del año 2000 de UNICEF no era menos escalofriante, en el que se calculaba que cuatro de cada cinco niños y niñas afganas no llegaron a cumplir los cinco años de edad (Unicef, 83). La esperanza de vida era de cuarenta y tres y cuarenta y cinco años para hombres y mujeres, respectivamente, y los niños morían de enfermedades comunes y fáciles de combatir, lastradas por la falta de atención sanitaria que solo alcanzaba al 29 por ciento de la población. De hecho, tan solo el 12 por ciento contaba con agua potable (Rashid, 2001, p. 166).

Los progresos que se habían dado en los años previos, durante la ocupación soviética, en la alfabetización se estancaron, el colectivo docente fue especialmente maltratado, debido a la enorme influencia que cobra la escuela en la implementación de la cultura y las ideologías (Griffin, 2001, p. 249) ${ }^{13}$. Las profesoras que impartían clases en la universidad o en los centros masculinos fueron expulsadas. Las que

${ }^{13}$ Se estima que fueron asesinados a 2000 docentes y otros 15000 fueron obligados a abandonar la profesión ante el temor de serlo también. 
protestaron fueron represaliadas, otras se exiliaron y algunas acabaron, lamentablemente, suicidándose al no poder soportar la asfixiante presión social sobre ellas (Gomà, 2011, p. 267). El rigorismo y la sharía impuesta por los talibanes trajeron consigo la invisibilización de la mujer, escondiéndola tras un muro de intransigencia y del tristemente conocido burka.

Aunque, desde entonces, tras la expulsión de los talibanes del gobierno de Kabul, la situación ha mejorado algo en el país (sin duda, habría sido imposible rodar el filme), celebrándose elecciones, todavía es muy precaria para las mujeres y la población en general, con muy leves avances debido a las dificultades internas. Al menos, en 2013, el Ministerio de Educación afgano lograba un enorme triunfo al conseguir que los talibanes permitieran que los jóvenes pudieran acudir a las escuelas con normalidad y garantizando la seguridad de los profesores (Apellaniz, 2017, p. 244). Pero, actualmente, la amenaza talibán se ha recrudecido (Monge, 2019).

Buda estalló por vergüenza es, ante todo, un ejemplo claro y demoledor de como el cine es capaz de sintetizar de una manera clara y precisa el devenir histórico y, al mismo tiempo, convertirse en un documento visual de enorme relevancia para sensibilizarnos, advertirnos y, sobre todo, acercarnos a contextos tan lejanos de la actualidad.

Bakhtay, Abbas y los demás niños actúan de una manera tan natural que casi parece que en ese juego de la imitación no distinguen entre realidad y ficción, enfatizando con ello el efecto que cobra el mundo adulto en los niños. Hana Makhmalbaf conseguiría con su desnudez y sencillez un gran logro visual, capaz tanto de conmovernos como de ofrecernos un mensaje un tanto negativo que evidencia que los adultos no somos capaces de escuchar a la infancia ni de tenerla en cuenta.

\subsection{Afganistán (II): La piedra de la paciencia (2012), de Atiq Rahimi ${ }^{14}$}

Situada en algún lugar conflictivo de Oriente Medio, La piedra de la paciencia aborda un punto de vista inusitado respecto a los otros filmes tratados. ¿Qué piensa una mujer musulmana cuando puede liberarse y contarle a su marido sus preocupaciones, sus miedos, sus desvelos, lo que ha sentido, realmente, a lo largo de su vida? El hecho es singular, desde luego.

La historia, dirigida por Atiq Rahimi, adaptación de su propia novela (galardonada con el premio Goncourt) (Rahimi, 2009), nos cuenta las vivencias de una joven que vela a su marido, en una ciudad sometida a la violencia de la guerra (no

14 Afganistán, 2012. Título original: Syngué Sabour (The Patience Stone). Productor: The Film. Dirección: Atip Rahimi. Guion: Jean-Claude Carrière y Atiq Rahimi. Música: Max Richter. Fotografía: Thierry Arbogast. Intérpretes: Golshifteh Farahani, Hamid Djavadan, Massi Mrowat, Hassina Burgan y Mohamed Al Maghraoui. Duración:102 min. Premios: Festival de Gijón: Mejor actriz (Farahani), FIPRESCl y premio del jurado joven (2012) y Premios César 2913: Nominada a Mejor actriz revelación. 
sabemos quién es el agresor ni quién el agredido). Este es un héroe de guerra mayor que ella y que, herido en el cuello (por causa de un insulto), se halla postrado, inerte, paralizado. Esto ha dejado a la mujer desamparada y resignada, con dos niñas de corta edad a su cargo. La guerra a su alrededor resulta implacable. Ha de cuidarlo y, al mismo tiempo, proteger a sus criaturas indefensas, así como a ella misma de los horrores de la violencia desatada a su alrededor. $Y$ mientras esto sucede se confiesa, como no podría haberlo hecho con su marido consciente, sobre sus sentimientos, miedos e ilusiones.

Su actitud parte de seguir rigurosamente con su rol pasivo y resignado (confiando en que en el rezo su esposo hallará la curación), pasando por sentir compasión por sí misma y honda desesperación, en su cotidiana adversidad, hasta su liberación emocional, mientras le confiesa a su marido silencioso quién es y lo que siente. Poco a poco, saca a relucir un carácter fuerte y resolutivo, urgida por la necesidad, comportándose de una forma valiente y resiliente, a pesar de las duras pruebas que le exige su situación y su condición de mujer, ante un mundo hostil.

Abandonada por la familia del marido, desasistida y sin recursos para vivir (el ingenio es lo único que le queda al no poder comprar medicinas ni comida), halla en una tía suya (prostituta) amparo y consuelo. Deja a su cuidado a sus hijas, lejos de su barrio amenazado, y a cambio la tía le relata su amarga experiencia vital, que no es sino la de tantas otras mujeres, casadas por su familia en un matrimonio de conveniencia.

Sin embargo, al no poder tener hijos, el marido la envía donde sus padres para convertirse en "su criada». Aunque esa circunstancia le permite a su suegro violarla impunemente, hasta que ella se harta, le mata y huye, haciendo creer que se ha suicidado.

Las dos parientes van revelando, así, en esta intimidad tan inusual, las idiosincrasias de una sociedad puritana y donde la sexualidad (sobre todo, femenina) es tabú o viene acompañada de arcaicos comportamientos (el mulá no entra a rezar con ella porque está impura, o lo que es lo mismo, tiene la menstruación ${ }^{15}$ ) (Kayaní y Zein, 2002, pp. 160-161; El Saadawi, 2017, p. 86). También ha de proteger a sus dos niñas, ingenuas, quienes creen que su padre está enfadado con ellas, pues no entienden su silencio, inconscientes de los padecimientos de su madre. Afuera, los hombres a lo suyo, a la violencia cíclica, sin medir los efectos sobre la población civil, en los ancianos, niños y mujeres, que han de encontrar refugio como pueden, con otros vecinos, en un sótano; dejando a su paso, un cúmulo de horrores (asesinatos) y destrucción (de edificios), saqueando, violando y robando.

La perspectiva psicológica no solo es original, dando total y absoluto protagonismo a la mujer, sino sumamente significativa. Perfila un universo femenino que

${ }^{15}$ En la historia ella lo utiliza como un arma que le permite alejar al religioso de su casa, al sentir que no obtiene ningún consuelo en la actitud resignada. 
va más allá de la mera resignación o subordinación, mostrando pensamientos y necesidades, liberando su propia frustración (y utilizando un lenguaje directo, impensable en otras circunstancias, ante el casto y rígido puritanismo), como cuando le dice a su marido con rabia: «Ahora me escuchas tú, para variar. Porque la verdad es que tú nunca me has escuchado». Y le reprocha sus ausencias, incluso la del día de su boda, siendo sustituido por un retrato de juventud y una daga; al estar siempre pensando en la guerra, lejos de ella, incluso cuando regresaba.

También cuenta cómo fue su vida (a modo de alegoría de cómo es la situación de la mujer en muchos países, tratadas casi como una mercancía, un objeto y como una molestia), con un padre obsesionado con las peleas de codornices, mostrando más afecto por estas que por su mujer y sus hijas. O como las pegaba si perdía, al venir de mal humor. En cierta ocasión, apostó por una codorniz, y no pudo hacer frente a las deudas. Por lo que dio a su hermana mayor, de 12 años, a un hombre de 40. Incluso le cuenta su secreto más oscuro, que dio a comer a un gato callejero la dichosa codorniz de su padre, por miedo a acabar como su hermana.

Ella comienza a comprender su áspera condición femenina, que le provoca una turbación interior por ir tan lejos en sus reflexiones, pero, a medida que eso ocurre y su situación se vuelve desesperada, ayudada por su tía, toma una conciencia inesperada y su marido herido se convierte en su piedra de la paciencia (una piedra mágica que sirve para desahogarse, que lo escucha todo hasta el momento en el que se rompe y, entonces, uno se libera de su dolor).

El largometraje se esfuerza en radiografiar una moralidad tradicionalista en la que la joven se ve entrampada y que es aplicable a estas sociedades arcaicas musulmanas. Donde es tan crucial la virginidad de la esposa en el matrimonio o el tener una prole pronto (si es varón, mucho mejor) (Kayaní y Zein, 2002, p. 114) ${ }^{16}$. 0 la decepción cuando eso no ocurre, derivando en que la suegra pida a su hijo que tome otra esposa, reduciendo el matrimonio a un mero acto procreador. $Y$ temor, en su lucha por no ser repudiada, ya que eso la habría conducido al estigma social y al rechazo de su propia familia, a la miseria y a la pobreza, a la indefensión (confiesa que sus hijas no son de él, era estéril, sino del chulo de su tía, quien se hizo pasar por un curandero).

A pesar de todo, de esta enorme desilusión y quebranto, la joven se resiste a dejarlo y, sobre todo, impide que le maten. Se desarrollará en ella un proceso de firmeza interior, encarándose, incluso, con unos milicianos (enemigos) que entran en su casa. Se hace pasar por una "prostituta» (Kayaní y Zein, 2002, pp. 81-92)17

16 «En el universo espiritual y en la psique del hombre y de la mujer musulmanas, la virginidad posee una importancia que les marca toda la vida».

17 Hay que pensar que, a pesar de su condena religiosa, existe y se da la prostitución en los países islámicos (al igual que los secuestros y tráfico de niños y niñas). Y en esa hipocresía religiosa se la considera impura, mientras que, si no lo es, se justifica como botín de guerra (p. 244). 
para que no la violen, a pesar del riesgo que corre por su vida. Pero eso no la librará de verse forzada, más tarde, cuando un joven chico tartamudo viene a buscarla, le paga por sus favores, y no le queda más remedio que transigir. Claro que esa relación se convierte en una fuente de satisfacción insospechada. Pues el joven muchacho es huérfano, un ser todavía más desvalido que ella y marcado por los horrores del contexto.

La joven desvela, así mismo, no solo una educación sexual inexistente o muy pobre, sino insatisfactoria, incluso en el seno del matrimonio, en el que ni el marido conoce ni le interesa conocer el cuerpo de su propia esposa (Kayaní y Zein, 2002, p. 115). Y se refleja bien cuando ella confiesa que en su primera noche de bodas no sintió nada salvo dolor, o que la única manera de encontrar placer era consigo misma, es decir, masturbándose, algo que desvela su insatisfacción sexual dentro del matrimonio. Y expresará: «Mi tía dice que los que no saben hacer el amor hacen la guerra».

De hecho, como señala Fernández Ruiz-Gálvez, «la violencia es un poderoso instrumento para mantener a las mujeres en situación de inferioridad» (2017, p. 285).

La piedra de la paciencia, con su alegórico título, se sigue con intensidad, a pesar de que se desarrolla, a nivel visual, de forma pausada y reflexiva.

La voz de la protagonista, nunca sabremos su nombre, ni el del resto de los personajes, su mundo interior, es lo relevante y singular. Cómo poco a poco va confesando su vida, sus emociones más profundas, sus secretos y miedos, algo que no es posible para una mujer en condiciones normales. La pugna que sostiene consigo misma por estar al lado de su marido, tal y como le han enseñado, a pesar de su indefensión ante la violencia que la rodea (lo que sirve para convertirlo, paralelamente, en un alegato pacifista), y al mismo tiempo su lucha heroica por defenderle y garantizar su supervivencia, en su abnegación, ahondan en un personaje femenino tan profundo como inusual. Desnuda y deja en evidencia la áspera, arcaica e insensible mentalidad patriarcal y, al mismo tiempo, reivindica un mundo rico en matices, como es el de la mujer. Incluso, introduce en la trama un elemento religioso a tener en cuenta: alude a la historia de Aisha, la mujer del profeta, quien le ayudó a centrarse en buscar la verdad de Alá, alejándose de sus propios demonios. Refuerza, con ese relato, no solo la visibilidad de la mujer musulmana, sino su relevancia en la Historia, su inteligencia y su resiliencia. 


\subsection{Arabia Saudí: La bicicleta verde (2012), de Haifaa Al Mansour ${ }^{18}$}

Es sabido que la sociedad saudí es una de las más retrógradas y conservadoras del Golfo Pérsico. Regida por una monarquía autoritaria y despótica, sostiene un rígido código de valores morales y religiosos: el wahabismo. Arabia Saudí pasó de ser un país atrasado, forjado en una cultura del desierto, escasamente urbanizada, a otra urbana y desarrollada, a nivel material, gracias a su riqueza petrolífera. Sin embargo, en términos sociales, es retrógrada, la mujer sostiene unos derechos muy restringidos y ha sido invisible a nivel público (finalmente, en 2015 se le permitió votar, aunque en sus propios colegios electorales). En palabras de la periodista Ángeles Espinosa, «no cabe duda de que la mujer se ha convertido en el elemento más contradictorio de la sociedad saudí, en un símbolo tanto de la opresión como del cambio" (Espinosa, 2006, p. 59). Hay que pensar que la sociedad saudí se encuentra vigilada por el denominado Comité (Comité para la Promoción de la Virtud y la Prevención del Vicio) (Mackey, 2004, pp. 94-98; Espinosa, 2006, pp. 90-96) quien controla, con su brazo policial, los mutawain, que se siga la ley y se encargan de «velar por una estricta segregación de sexos» (Martin, 2013, p. 116). La misma directora, Haifaa Al Mansour, vivió en sus propias carnes esta discriminación (mientras rodaba) y fue por ello que intentó llevar a cabo un acercamiento honesto y «no ofensivo» (Ayuso, 2013) a esta realidad. Sin embargo, poco podría haber hecho para rodar una película de tales características en las mismas calles de Riad sin el apoyo de la productora Rotana del príncipe Al-Waleed, comprometido con los derechos de las mujeres (Meneses, 2017).

La bicicleta verde tuvo una acogida muy favorable en los países occidentales logrando importantes menciones (Meneses, 2017). Aunque su mayor logro fue que participó como Mejor Película Extranjera en la gala de los Oscar de Hollywood. Era la primera vez que eso sucedía con una película saudí y con una temática tan sensible para la opinión pública de este país, como es la situación de la mujer (Filmaffinity).

La trama nos presenta a la joven Wadjda (su nombre es el título original del filme), una niña saudí rebelde y cuyo gran sueño es comprar una bicicleta verde para poder competir y ganarle en una carrera a su amigo Abdullah. Wadjda vive a las afueras de Riad con su madre, quien no puede tener más hijos, por lo que la familia de su marido aspira a que este se case con otra mujer que pueda ampliar su progenie (Tarrés, 2019, p. 98) ${ }^{19} \mathrm{y}$, sobre todo, que traiga hijos varones.

18 Arabia Saudí-Alemania. 2012.Título original: Wadjda. Directora: Haifaa Al-Mansour. Guión: Haifaa Al-Mansour. Música: Max Richter. Fotografía: Lutz Reitemeier. Reparto: Reem Abdullah, Waad Mohammed, Abdullrahman Algohani, Sultan Al Assaf, Ahd Kamel. Duración: $98 \mathrm{~min}$.

19 Un hombre musulmán solo está completo si se casa y tiene hijos (varones). 
Las niñas no cuentan en el árbol familiar que hay dibujado en la pared de la casa. Para lograr su objetivo, Wadjda, a pesar de las reticencias y negativas de su entorno, se empeña en ganar un concurso organizado en el colegio de recitado del Corán. El sueño de conseguir su bicicleta se convierte en una metáfora sobre la liberación de las normas y rígidas actitudes conservadoras de las mujeres saudíes, en un tono sencillo, amable e, incluso, divertido, visto con los ojos vitales de una niña (Espinosa, 2006, pp. 36-37) ${ }^{20}$.

La joven directora es capaz de acercarse a un universo cerrado y tan restrictivo desde una óptica adecuada, porque podría haber sido un retrato mucho más descarnado de la vida de muchas mujeres en ese país. No esconde su situación, pero tampoco va más lejos (describe a la clase pudiente, no a la que pasa más necesidades, y tampoco se adentra en el maltrato doméstico).

Las vicisitudes y las relaciones de Wadjda con su entorno (con su padre y su madre), así como con su profesora y su amigo Abdullah son muy reveladoras del mundo que la joven directora describe y radiografía. Nos presenta a las mujeres que viven sometidas a unas reglas muy marcadas. En el espacio público las que son adultas no pueden salir sin el abaya, y las jóvenes deben ir obligatoriamente con el pelo tapado (Caferri, 2013, p. 80; Espinosa, 2006, p. 28). Cuando salen a la calle los espacios están estrictamente segregados. Así, las compras las realizan en centros comerciales exclusivos para mujeres (Caferri, 2013, p. 89) ${ }^{21}$. Ello hace observar el enorme contraste entre la modernidad existente (en lo material) y los arcaísmos sociales, donde el cuerpo y el rostro de la mujer deben esconderse (hay una censura muy estricta, a este respecto, en todos los medios). Incluso, como no hay probadores en las tiendas, debe ir al baño para poder saber cómo le sienta la ropa.

Al mismo tiempo, no son libres para andar fuera de sus domicilios solas. 0 , ya, no ser visibles desde fuera. Así que cuando Wadjda y su madre observan desde la terraza una fiesta al otro lado de la calle, deben tener cuidado en no ser vistas, sería deshonroso.

En el largometraje, la madre de Wadjda debe contratar un trasporte privado, compartido con otras mujeres, para salir o ir a trabajar (todavía, en ese contexto, no se había aprobado que pudiesen conducir, con lo que remarca aún más las constricciones existentes). $\mathrm{Y}$, a pesar de las quejas que tienen contra el conductor, no les queda más remedio que aceptarlo, indefensas, porque de otro modo no podrían salir de casa. Pues, aunque ya muchas han logrado cursar estudios superiores, e

${ }^{20}$ La primera mujer que pidió poder ir en bicicleta a su centro de estudios, en 1959, ante el Comité tuvo muchos problemas al considerar que este medio de transporte moderno era un instrumento diabólico.

${ }^{21}$ Pero, incluso, hay centros con lugares reservados exclusivamente para mujeres, con guardias que impiden que accedan hombres, donde aquellas pueden ir sin el nicab. 
introducirse en el mercado laboral, no gozan de la independencia total y absoluta en algo tan básico como poder desplazarse a sus trabajos con libertad.

La película nos presenta a una familia de clase media alta, pudiente. Pero, a pesar de que la madre trabaja fuera de casa, esta está siempre pendiente de la visita del marido como rey de la casa. Él no debe preocuparse de nada, salvo de ser complacido y agasajado por su mujer e hija, aunque no pregunta nada sobre su progreso en la escuela. Sin embargo, a pesar de esta situación privilegiada, el hombre tiene sus propias tiranías sociales porque, aunque no lo desea, es obligado por su familia a casarse con otra mujer para, así, conseguir hijos varones.

El otro aspecto de enorme relevancia radica en la educación que se recibe en los centros públicos. En ellos se presta una cuidada atención a los preceptos religiosos que garantizan su propia sumisión y la primacía del patriarcado (El Saadawi, 2017, p. 87). La actitud celosa y tan guardiana de la dignidad femenina de la directora del centro, Hussa, es muy llamativa y simbólica a este respecto. Es una mujer soltera amargada que se ve presa de las tradicionales convenciones sociales, pero, al mismo tiempo, castiga e impone rígidamente los dictados religiosos y morales. Y cuando cree que ha conseguido domar a Wadjda, su desilusión es enorme al darse cuenta de que no es así.

La misma madre de la protagonista, tan quejosa y desdeñada por esta mentalidad vetusta, al no poder procrear, también desvela una mentalidad conservadora, sin ser consciente de que es la misma que le hace ser esclava de su sometimiento y sufrimiento. Lo vislumbra cuando un familiar le propone servir de enfermera y se encuentra que, en el hospital donde podría trabajar, las mujeres van con el rostro descubierto y hombres y mujeres desarrollan la labor médica conjuntamente...

Haifaa Al Mansour va desnudando la realidad de una forma clara y precisa, pero permitiendo que sea el espectador quien juzgue los hechos, la situación de indefensión de las mujeres, atrapadas tanto por su propia mentalidad como por las rígidas normas imperantes que las hacen, a pesar de sus virtudes, tener que ser invisibles o vivir padeciendo las retrógradas actitudes morales. Así, la joven Wadjda encarna la rebeldía y la confrontación (de hecho, que sea una niña la protagonista ya tiene su carácter reivindicativo). Y su propia ingenuidad y aspiraciones la convierten en un icono manifiesto de que no hace falta llevar a cabo una revolución social, tan solo una comprensión de la injusticia que padece la mujer saudí, víctima y cómplice de sus propias cadenas.

De hecho, al final, hay una nota de optimismo cuando la propia madre es la que le compra la bicicleta a Wadjda, tras tanta resistencia, y reconoce su derrota al conocer como su marido ha concertado otra boda. La bicicleta verde señala, así, los caducos comportamientos de una sociedad que oculta y niega a sus mujeres su derecho a vivir felices y dignamente. Sin que eso suponga un ataque, ni mucho menos, ni una renuncia al islam. Tal y como señala Aguirre, «la revolución de la mujer saudí comienza tras las ropas, tras los muros, tras las costumbres, de aparentes batallas pequeñas pero que requieren enormes esfuerzos» (Aguirre Romero, 2014, p. 122). Y el cine nos lo desvela. 


\subsection{Irán: Persépolis (2007), de Marjane Satrapi y Vincent Paronnaud ${ }^{22}$}

El caso de la historia de Irán es especial. País persa y musulmán, vivió una época prooccidental durante el periodo del reinado de la familia Pahlevi. Sin embargo, en 1979, la Revolución Islámica expulsó a los monarcas, cuyo gobierno despótico y arbitrario no supo encarar los problemas del país, e instauró un gobierno teocrático. Las normas sociales se vieron alteradas de la noche a la mañana.

El integrismo sustituyó al progresismo y a las modas occidentales introducidas. Y la situación de la mujer cambió por completo. Desde entonces, transcurridas ya varias décadas, la sociedad iraní ha ido cambiando. Se ha consolidado un modelo social contradictorio, atrapado entre el progreso material y un rígido y celoso control religioso (Díaz-Maroto, Carrillo y Puebla, 2014, pp. 313-314) ${ }^{23}$. Además de verse afectado duramente tanto por la guerra con Irak (1980-1988) como por sus pugnas y rivalidades con otros países del entorno, especialmente, con Arabia Saudí y EE. UU. (Adelkhah, 1996; Kayani, 1998; Axworthy, 2010; Armanian y Zein, 2012).

Persépolis es la adaptación animada de la novela gráfica pergeñada por Marjane Satrapi ${ }^{24}$, que relata sus experiencias vitales en Teherán, antes y después de la revolución jomeinista, hasta su marcha definitiva a Europa. Un diseño de viñetas muy cuidado nos desvela y desnuda una realidad, el proceso en el que Irán se fue convirtiendo en una sociedad teocrática ${ }^{25}$.

En su primera etapa, la protagonista, Marji, es una niña feliz con su vida. De hecho, sus palabras son muy significativas: «Recuerdo que en aquella época

22 Francia, 2007. Título original: Persépolis. Productor: 2.4.7. Films. Dirección: Marjane Satrapi, Vincent Paronnaud. Guion: Marjane Satrapi, Vincent Paronnaud (Cómic: Marjane Satrapi). Música: Olivier Bernet. Fotografía: Animation (B\&W). Duración: 95 min.

${ }^{23}$ Por ejemplo, al principio, el cine de la Revolución prohibía abordar temas como las relaciones de una pareja que no estuviese casada o emparentada, efusión física (salvo si son niños), la crítica al matrimonio musulmán, al sistema político, un primer plano femenino, por incitación sexual. Si bien, luego, a trancas y barrancas ha ido rebajando ese cerrado nivel de censura, permitiendo el abordar temas sociales relevantes.

${ }^{24}$ La misma novela gráfica recibiría muchos galardones y premios como el Prix du Lión (Bélgica, 2000), el Premio al autor revelación (Angouleme, 2001), Premio al mejor guion (Angoleme, 2002), Primer Premio de la paz Fernando Buesa Blanco (Vitoria, 2003) y Premio Harvey (EEUU, 2004).

${ }^{25}$ Cosechó un éxito tremendo con un sinfín de galardones y nominaciones: Nominada a mejor película de habla no inglesa y de animación, Premios BAFTA British Independent Film Awards (BIFA) (2008); nominada a Mejor película de habla no inglesa en los Oscar y Globos de Oro (2007), Premio del jurado del Festival de Cannes (2007), Mejor ópera prima y guion adaptado, Premios César (2007), Premio a la libertad de expresión, del National Board of Review (2007), Mejor película de animación del Círculo de Crítico de Nueva York y Asociación de Crítica de Los Ángeles (2007), y nominada como mejor película o film de animación en los Premios Annie, Critics' Choice Awards, Asociación de Críticos de Chicago y Premios Independent Spirit (2007). 
llevaba una vida tranquila y sin problemas. Una vida de niña. Me encantaban las patatas fritas con kétchup. Bruce Lee era mi héroe. Llevaba unas Adidas. Y tenía dos grandes obsesiones: poderme depilar las piernas algún día y convertirme en la última profeta de la galaxia». Lo cual es muy indicativo de que la vida cultural iraní contiene una gran influencia oriental y occidental. Vive con sus padres, Ebi y Tadji, y mantiene una estrecha relación con su abuela, una sabia mujer. Son los últimos estertores del gobierno del Sah y se nos muestra una sociedad occidentalizada, pero no ideal, ya que es una época en la que comienzan las primeras manifestaciones contra la monarquía.

Marji encarna en este tiempo la ingenuidad, cree que el Sah fue investido por Dios, como le enseña su maestra en la escuela. Y pone el acento, como lo hará más tarde, en el valor tan alto que se tiene del adoctrinamiento en la educación. Sin embargo, su padre, un hombre culto y periodista, le explica el origen de la monarquía. Cómo el padre del Sah pergeñó un golpe de Estado contra el emperador Qadjar y que al principio pretendió instaurar una República como la turca, pero que los ingleses le disuadieron para que estableciese su propio gobierno autoritario, a cambio de cederles intereses en el petróleo. Como rasgo positivo, eso sí, destaca que modernizó Irán (Armain y Zein, 2012, p. 89) ${ }^{26}$. Pero su hijo fue mucho más torpe que el padre, y llevó a cabo una gran persecución política anticomunista, incluido el abuelo de Marji.

Esta influencia familiar convierte a Marji en una activista contra el Sah, mostrando, así, el cambio social que se estaba produciendo.

Las imágenes no solo relatan, sino que expresan muy bien la situación política caótica de Irán, con capítulos reservados a las torturas, a la liberación de presos y a los últimos intentos vanos del Sah de llevar a Irán hacia la democracia. Y cómo este ambiente es absorbido por Marji y sus amigos, quienes no dudan en intentar atacar a un chico cuyo padre ha sido un torturador de los servicios secretos del Sah. Y, de pronto, "los enemigos de ayer, se convirtieron en héroes nacionales». Entonces conocerá a su tío Anouche, quien encarna a aquellos que pugnaron contra el Sah y fueron perseguidos. Él se pudo salvar, pero otros, como su hermano, no tuvieron tanta suerte.

De forma sencilla, directa e ilustrativa, las viñetas van sintetizando bien ese proceso en el que se recoge la historia de Irán, el efecto que esto provoca en los distintos personajes, sobre todo en Marji y sus padres, a lo largo de este tiempo.

Claro que la parte central reside en mostrarnos esa nueva Irán nacida de las cenizas de la revolución jomeinista. Los antiguos disidentes laicos o demócratas son orillados por un grupo social emergente que a nivel internacional no fueron tenidos en cuenta (Armain y Zein, 2012, pp. 261-262): los islamistas. El mismo Anouche explica a Marji que las primeras elecciones trajeron consigo su triunfo, debido al

\footnotetext{
${ }^{26}$ A tal fin, dio lugar a que de Persia pasase a llamarse Irán.
} 
alto analfabetismo y a que la población encontró en la religión su refugio (Armain y Zein, 2012, 264-265) ${ }^{27}$.

De forma clara y precisa, se va desvelando esa transformación en la que se recortan las libertades, imponiendo el modelo de una sociedad teocrática islámica vigilada estrecha y muy celosamente por los Guardianes de la Revolución. La mujer tiene que portar obligatoriamente el chador (Armain y Zein, 2012, pp. 76-84) ${ }^{28}$, prohibiendo todo aquello que vaya contra la integridad de la rígida y estricta moral como el alcohol, música occidental, juegos de cartas, cosméticos, etc. Aunque, en paralelo, va a florecer un mercado negro que ofrece dichos productos. El largometraje analiza de forma genérica, pero muy implicativa, el tema de cómo afectan específicamente las nuevas leyes a los iraníes. La sociedad entera se ve afectada profundamente por esa visión rigorista y eso perturba a un colectivo muy importante: la mujer.

Otro elemento que destaca es la afección que provocará la larga guerra con Irak (1980-1988) en las madres. No solo por las privaciones y el efecto traumático de los bombardeos aéreos en Teherán, sino porque la suerte de los jóvenes que acaban muriendo a miles en el frente se convierte en el panegírico de las virtudes del buen musulmán, de la gloria del martirio, mientras las madres se ven obligadas a llorarlos. Muchos jóvenes, de 14 años, se ven atrapados por la propaganda y creen que su muerte les llevará al paraíso con cientos de mujeres aguardándoles. No lo piensan así sus madres, que sufren la pérdida de sus hijos. Lo cual es un retrato desnudo del grado de fanatismo al que se tuvo que llegar para alimentar la maquinaria de la guerra.

A pesar de este ambiente opresivo y cerrado, hay una rica, y peligrosa, vida clandestina (fiestas) que se resiste, a su manera, a la asfixia social existente. Humor, drama y crítica social se van desgranando en este retrato tan original (a nivel visual y conceptual), como cuando la familia de Marji debe tirar el alcohol, ante el temor a ser detenidos. Pero también está la tragedia, como la suerte que corre su tío Anouche que se convierte en víctima de la justicia de la revolución; o cuando el tío Taher, necesitado de una operación de corazón, fallece, tras el inútil intento de Ebi de conseguir un pasaporte falso para su salida de Irán.

27 Con suma habilidad se produjo un referéndum entre el 30 y el 31 de marzo para que los iraníes eligiesen entre República Islámica sí o no. Sin embargo, nadie sabía que iba a implicar un sí, una negativa parecía traer consigo la aquiescencia del regreso del Sah, algo que nadie quería. Hubo voces críticas que consideraron que debería haber más opciones o ya asegurar una República islámica democrática, pero no prosperaron. Finalmente, sería aprobada por el 99,35 $\%$ de los votos.

${ }^{28}$ El tema del controvertido velo no era nuevo, ya arrancaba a inicios del siglo, en el que los clérigos se enfrentaban a la occidentalización de las costumbres y la voluntariedad de cubrirse o no la cabeza. En 1934, el Sah acabaría por prohibir el velo, trayendo consigo muchas protestas y reacciones sociales contrarias (muchos padres prohibieron a hijas y esposas salir a la calle por eso). 
La misma Marji, educada en una familia liberal, y que encarna a una joven rebelde, franca y audaz, también se mete en serias dificultades con los rigoristas, como cuando discute con su maestra (la misma antes tan partidaria del Sah) sobre la existencia o no de presos políticos, y denuncia la situación de opresión existente. Por temor a que puedan ajusticiarla (no sin antes violarla porque en Irán no se ejecutan vírgenes), sus padres deciden enviarla lejos, a Austria.

Su periodo austriaco trascurre entre la inadaptación y la negación de su propia identidad iraní. Pues, como confiesa Marji, la gente piensa que son solo "fanáticos que se pasan todo el día peleando». Pero su carácter muestra que no es así. Vive, eso sí, en su maduración, diferentes experiencias, engaños y desengaños amorosos que la llevarán, finalmente, a pasar por una amarga experiencia viviendo la penuria del hambre y la desesperación, enfermando gravemente.

La añoranza de su tierra puede más y regresará, ya hecha una mujer, a su Irán. Y ahí comienza ya su última etapa antes de su despedida definitiva.

«Nada había cambiado. Pero nada volvería a ser como antes», dictamina a su regreso. Pues la guerra, a pesar de todo, ha marcado de forma irremediable la vida y a la propia Teherán, cuyas calles tienen nombres de mártires. Por lo que su madre le dice: «Y ahora, al pasear por Teherán, tienes la sensación de estar en un cementerio». Sin embargo, adaptarse no le es sencillo. Al principio, Marji pasa por un periodo depresivo, hasta que se pone a estudiar arte. $Y$ de nuevo, sale a relucir su rebeldía ante una sociedad marcada por las pautas del rigorismo más absurdo, añadido al hecho de su papel como mujer. Pues «las mujeres han estado en el centro de los conflictos sociales de Irán desde la entrada de la modernidad» (Díaz-Maroto, Carrillo y Puebla, 2014, p. 318).

Tiene que estudiar un arte censurado, una anatomía del cuerpo que se reduce a la cara y soportar las estrictas y absurdas normas de la longitud del obligatorio chador o la anchura de sus pantalones, para evitar que se vean sus formas, mientras sus homólogos masculinos visten como quieren. Tal y como señala El Saadawi (2017, p. 192), «la ortodoxia religiosa provoca una fuerte represión sexual». 0, a pesar de que estudian en los mismos centros están rigurosamente separados, algo que no sucede en otros espacios sociales (Díaz-Maroto, Carrillo y Puebla, 2014, p. $323)^{29}$. El salir de fiesta se convierte en un delito que acaba en tragedia, cuando un amigo suyo muere huyendo por los tejados de los celosos Guardianes de la Revolución. Sin duda, en el mundo del integrismo el ocio, la diversión o cualquier disfrute personal están prohibidos (Kayaní y Zein, 2002, p. 270). Es una sociedad gris y triste. Incluso, para poder ir en pareja, se ve obligada a casarse prematuramente con su novio, Reza. Aunque su convivencia es fallida porque lo hacen sin conocerse. Hasta

${ }^{29}$ «Si, por un lado, las mujeres iraníes pueden conducir automóviles, montar negocios y vivir una vida casi normal dentro de la casa, en la vida pública, hay separación de sexos: segregación en autobuses, en playas, en piscinas, en celebraciones». 
que se da cuenta de que no tienen nada en común y decide divorciarse, si bien sabe que eso puede estigmatizarla. Al final, la única manera de ser fiel a ella misma, independiente y feliz, como iraní, es yéndose a vivir a Francia.

La audaz, amarga y aguda ironía del retrato de la sociedad iraní que se hace en Persépolis nos narra la historia de Irán a lo largo de varias décadas. Es una mirada muy personal, desde luego, pero que clarifica muy bien esa involución y contradicciones existentes provocadas, primero, por el mal gobierno del Sah y, luego, los efectos tan dañinos provocados por la Revolución, ante la falta de libertades sociales y el rigorismo islámico vigilante y estricto. Pero, ante todo, la complicidad del dibujo con la imagen (además de la música, claro), se convierte en una mirada crítica que nos permite observar y juzgar la situación de la mujer en Irán que, para tener que ser feliz o lograr sus metas personales, ha de marcharse de su tierra (DíazMaroto, Carrillo y Puebla, 2014, p. $319^{30}$.

\subsection{Turquía: La fuente de las mujeres (2011), de Radu Mihaileanu ${ }^{31}$}

Inspirada en una noticia de un hecho sucedido en Turquía, una huelga de sexo (El espectador) ${ }^{32}$, el director rumano Radu Mihaileanu llevaría a cabo un retrato de la situación femenina musulmana desde la fábula cinematográfica.

La historia no es nueva, el primer acontecimiento singular de estas características aparecía recogido en la obra Lisístrata, escrita por Aristófanes, en el 411 año a. C. En ella recoge como las mujeres atenienses y espartanas iniciaron una huelga de estas características para poner fin a las Guerras del Peloponeso entre ambas polis (De la Villa Polo, 2004). Tan singular acontecimiento ha servido de inspiración y emulación en otros contextos (Higueras, 2011) ${ }^{33}$.

${ }^{30}$ Todo ello matizable, por supuesto. Porque a pesar de esos aspectos negativos, la mujer ha alcanzado unas tasas en la universidad muy elevadas, siendo el $62 \%$ de las estudiantes. Eso ha comportado su incorporación al mercado laboral y le ha dado mayor entidad, aunque, ya, habría que referirse a inicios del siglo xxi. Pero el marido, a pesar de todo, sigue siendo la piedra angular de la familia.

${ }^{31}$ Bélgica, Italia y Francia, 2011. Título original: La source des femmes. Dirección: Radu Mihaileanu. Guion: Radu Mihaileanu y Alain-Michel Blanc. Producción: Radu Mihaileanu, Luc Besson, Denis Carot, Gaetan David, André Logie y Marie Masmonteil. Música: Armand Amar. Fotografía: Glynn Speeckaert. Diseño de producción: Christian Niculescu. Vestuario: Viorica Petrovici. Interpretación: Leïla Bekhti, Hafsia Herzi, Biyouna, Salek Bakri, Sabrina Ouazani, Hiam Abbass, Mohamed Majd. Duración: 135 min.

32 En la ciudad de Irka, en 2009, cuando las mujeres presionaron de este modo a sus maridos para lograr que trajeran agua potable al pueblo.

33 Por ejemplo, En 2003, Leymah Gbowee y la asociación Women of Liberia Mass Action for Peace, adaptaron los mismos principios para impulsar a poner fin a la guerra en Liberia, lográndolo. 
La película transcurre ambientada en un pequeño pueblo rural afectado por la sequía, donde las mujeres se dedican a las tareas del hogar y a la dura e ingrata labor de acarrear agua de una fuente en la montaña, mientras los hombres permanecen sin nada que hacer. Estos pasan sus tardes de tertulia y tomando té. Hasta que un buen día, como sucede cada año, una de las mujeres resbala y eso le provoca un aborto. La alegría de una inminente boda se ve enturbiada por esta terrible circunstancia y suscita que la joven Leila muestre toda su amargura. Denuncia que es una realidad insostenible y decide rebelarse y pedir a los hombres que se encarguen de llevar el agua corriente al pueblo, para evitar tales tragedias. Para conseguirlo les propone a todas ellas una huelga de amor (en otras palabras, no practicar sexo con sus maridos hasta que se hagan cargo de la situación y tomen una solución). A pesar de las dudas y reticencias de muchas de ellas, como Fátima, la suegra de Leila, la más veterana y la que ejerce más influencia, Madre fusil las acaba por convencer. La reacción de sus maridos es de total incomprensión y cerrazón (salvo Sami, el marido de Leila que la apoya), piensan que así ha sido siempre, es la tradición que acarreen el agua, lo que provocará una guerra de sexos. Tampoco todas las mujeres aceptarán bien este compromiso, porque confronta a la comunidad y se generarán múltiples tensiones. Pues la sexualidad en el matrimonio se considera tanto un derecho como un deber que hay que cumplir (Ruíz de Almodóvar y Sel, 1988, p. 236).

Lo que deja bien patente el largometraje, en su alegoría, es que las tradiciones deben cambiar y adaptarse a los nuevos tiempos. Si los roles antaño estaban bien definidos, los hombres guerreaban y cumplían con sus tareas en el campo, y las mujeres se dedicaban al hogar, ahora, en ese nuevo contexto de paz y sequía, ¿ por qué las mujeres deben sobrellevar de forma tan dura la situación mientras los hombres no hacen nada por mejorarla, despreocupados?

La rebelión femenina se convierte así en una confrontación entre las nuevas mentalidades, lideradas por Leila, en el lado femenino, y Sami, en el masculino, y las viejas, por Fátima y el resto de hombres, que consideran que socaban el orden que siempre había regido hasta entonces. Leila sufrirá toda clase de presiones, de su suegra o de su propia familia (que vive en otra localidad), ya que todos consideran que lo que está haciendo es negativo. Hasta el mismo imán habla con ella para intentar disuadirla de sus planes. Pero no irá sola, el compromiso de la mayoría de las féminas es total y, además, Sami, el maestro, la ayudará y le permitirá convencer al propio imán de que su reivindicación no pretende subvertir las leyes coránicas sino defender su dignidad (Kayaní y Zein, 2002, pp. 168-169) ${ }^{34}$.

${ }^{34}$ Pues si bien el marido tiene derecho a un «libre acceso sexual» con su esposa, esta también tiene el derecho de ser mantenida adecuadamente (nafague). Lo que hace Leila es darle la vuelta al argumento y primar el derecho de la esposa sobre el del marido. 
También, la trama no duda en denunciar la actitud hipócrita de las propias autoridades públicas, quienes deberían ser las que impulsaran el progreso social, pero que lo hacen de una forma torpe y muchas veces fallida, al no atender las demandas más elementales de la población (como luz y agua), todo porque los intereses políticos priman sobre la sociedad.

Curiosamente, los hombres temerán menos la merma de su estatus que la vergüenza que puedan pasar por que otros pueblos sepan que no pueden ocuparse de sus mujeres. Y, por supuesto, intentarán por todos los medios evitar que eso ocurra y que estas asistan a una gran festividad para denunciar (mediante cánticos) dicha realidad (las pretenderán secuestrar). El orgullo y su propia vanidad les hace ser sordos y ciegos a las lícitas reivindicaciones de sus esposas e hijas, y a su padecer cotidiano y su sufrimiento.

La fuente de las mujeres trasciende al contexto y se convierte en un alegato tierno, con ciertas dosis de humor y paternalismo, sobre la situación de las mujeres musulmanas en ciertas áreas atrasadas y su enorme sagacidad e inteligencia para ganarles la partida a sus homólogos masculinos. Cabe señalar que las mujeres no reivindican igualdad jurídica, aunque vaya implícita, sino justicia social. Tampoco es un ataque al Islam, al contrario, sino al machismo entendido desde una perspectiva de cerrar los ojos a una realidad que debe adaptarse a las necesidades presentes. Y, en su lado más romántico, también reivindica la importancia que cobran los matrimonios por amor, y denuncia los matrimonios concertados que arruinan la relación de tantas parejas que se quieren, pero que debido a los intereses familiares no pueden casarse.

La historia ha de interpretarse como una metáfora muy elocuente (atemporal y ahistórica) que, dentro de una reivindicación justa, es comedida, porque no pone en entredicho la jerarquía existente, sino la incapacidad del género masculino por estimar la labor de sus mujeres y mostrar el valor del amor (en su parte más dulce y amarga).

Y aunque, a su término, el logro de poner la fuente en el mismo pueblo parece cerrarse en falso, nada queda igual. Deja una puerta abierta a un nuevo marco de oportunidades que se abrirán con la joven Esmeralda quien, tras un grave desengaño amoroso, da el valiente paso de salir del pueblo y buscarse la vida lejos de él. Decide elegir libremente, aunque rara vez la mujer musulmana puede hacerlo, se rebela, en este caso, abriéndose hacia un final esperanzador, frente a las reglas sociales impuestas (Kayaní y Zein, 2002, p. 175). Ya no aguarda, sino que es quien sale a buscar su vida, deja de ser una mujer pasiva (El Saadawi, 2017, p. 190). 


\subsection{Yemen: 10 años y divorciada (2014), de Khadija Al-Salami ${ }^{35}$}

Yemen, enclavado al sur de la península arábiga, es una sociedad muy tradicional, al menos, hasta la desolación que trajo consigo la primavera árabe, la guerra civil y, por supuesto, la intervención de otros países en el territorio (como su vecino Arabia Saudí) (Aguirre, 2015, pp. 32-39; Medina, 2018, pp. 91-111).

Es un país de grandes contrastes sociales (norte y sur). Unificado tardíamente en 1990, se contemplaba el derecho al sufragio universal y la posibilidad de las mujeres de ser elegidas parlamentarias, como los hombres, cumplidos los 35 años. Sin embargo, ciertos costumbrismos fuertemente arraigados no han podido ser sustraídos. De este modo, las mujeres, sin límite de edad, veían como eran (y son) casadas como si fuesen un bien familiar. Desde muy jóvenes, por lo tanto, pierden no solo su infancia sino su independencia, debiéndose a la familia y a la tradición (Álvaro Navarro, 2019) ${ }^{36}$. Esto no quiere decir que no se haya dado un movimiento feminista relevante, ni que se impulsasen leyes igualitarias, eso sí, restringidas por el sistema patriarcal e islámico. Muchas mujeres accedieron a la educación primaria, secundaria y superior y, en 1996, se constituyó el Comité Nacional de Mujeres (NWC). Desde entonces, la lucha contra la legislación que limitaba sus derechos ha proseguido (Badran, 2012, pp. 394-421). Si bien, como ya se ha mencionado, la guerra ha paralizado cualquier proceso de cambio.

Khadija Al-Salami, guionista y director, nos acerca en 10 años y divorciada a una realidad anterior al conflicto, pero muy relevante, para ofrecernos un punto de vista sobre la situación de la mujer yemení (aunque susceptible de ser extendido a otras sociedades), subrayando su maltrato y su indefensión frente a sus maridos (niñas convertidas en esposas, matrimonios pactados, estigmatización, servilismo y el tema del divorcio).

La trama nos cuenta la historia de Noojom (significa Oculta) quien vive en un pueblo del interior, junto a su padre y seis hermanos/as. La situación familiar es dura y exigente, viven de la recolección del café y del ganado, en las montañas, en una zona agreste y llena de peligros (barrancos y piedras que se deslizan), son relativamente felices, con un padre que se muestra cariñoso y amable, y con sus hermanos mayores que la tratan con respeto, juega con ellos o le enseñan sus quehaceres. Aunque eso no evita los problemas tribales relativos a la familia (el padre

35 Yemen, 2014. Título original: Ana Nojoom bent alasherah wamotalagah. Productora: Benji Films / Hoopoe Film. Director: Khadija Al-Salami. Guion: Khadija Al-Salami. Música: Tierry David. Fotografía: Víctor Credi. Intérpretes: Reham Mohammed, Adnan Alkhader, Sawadi Alkainai, Rana Mohammed y Ibrahim Alashmori. Duración: 96 min.

36 De hecho, el problema se ha agravado con el conflicto: "La guerra, el hambre y el analfabetismo son culpables de que el matrimonio infantil haya condenado a muchas menores a convertirse en esposas demasiado pronto. Las cifras se han disparado, del 17,1 \% en 2013, según datos del Gobierno yemení, al 72 \% en 2018 según Unicef». 
de Noojom ha contraído nupcias con una segunda esposa, obligado por su familia, mientras que la madre de Noojom ha vuelto con los suyos por una ofensa hecha por el padre de su marido), ni la cruda realidad femenina, cuando una de sus hermanas es violada por un pastor. Pues «la cultura musulmana considera [que] el cuerpo de la mujer [es] como un receptáculo del honor de la familia» (Kayaní y Zein, 2002, p. 145). Y el criminal, protegido muchas veces por la ley, queda impune, mientras la mujer o la familia cae en la deshonra (El Saadawi, 2017, p. 95). En ese caso, el padre exige restaurar su honor (a veces con un pago, como en el filme, otras con una restitución con sangre), si bien, descubierto lo ocurrido, ante la humillación social no tiene más remedio que marcharse del propio pueblo donde ha vivido y crecido ((Kayaní y Zein, 2002, p. 146) ${ }^{37}$. Con una vida tan rigurosa, Noojom no tiene ocasión de disfrutar mucho de la infancia (debe cuidar junto a su hermano Sami las ovejas o dar de comer a los pollos), menos aun cuando debe casarse con un hombre 20 años mayor que ella. Claro que las condiciones del matrimonio serán opresivas para ella. De tal manera que, un buen día, aprovecha la circunstancia de tener que hacer un recado para escaparse, presentarse en un juzgado y pedir a un juez el divorcio...

Sin ser un filme artísticamente redondo, no hay duda de que se encara con un tema muy delicado y que no gustará al tradicionalismo al denunciar la violencia de género, sin tapujos, y también la situación de la desprotección de la infancia. Es ante todo un retrato antropológico de la sociedad tribal. Se lleva a cabo una matizada radiografía de un país tan diferente y lleno de contrastes. Tanto en las zonas rurales de alta montaña, donde vive la familia protagonista al principio, sin lujos y diminutas poblaciones, como en la inmensa ciudad, donde se trasladan a vivir después, y zonas urbanas más desarrolladas, si bien las mujeres van todavía más tapadas que en el campo (todas de negro), las mentalidades son igual de conservadoras y cerradas. Y su vida cambia por completo.

Si antes vivían en una casa, ahora la familia se ve obligada a vivir más estrechamente en dos habitaciones ("¿ंesto es una casa o un establo?» es el comentario de Noojom), en un suburbio, ya que el padre no se puede permitir nada mejor. $Y$ ahí se muestra la disimilitud entre el campo y la ciudad, pues un humilde campesinoganadero está más indefenso en la gran ciudad, donde el nivel de vida es muy alto.

Si bien, el punto central de la historia reside en la boda de Noojom que a su edad debe aceptar el acuerdo que su padre ha hecho con un hombre, al que no conoce, para sus nupcias. La dote del marido (mehriye) es lo que les permite pagar el alquiler del humilde hogar y sostener a sus hijos y a sus dos esposas (enfrentadas una con la otra). En otras palabras, para su familia es una garantía de supervivencia ante la precariedad en la que se encuentran. Pero, por otro lado, subraya esa

${ }^{37}$ La única protección legal a la que puede recurrir una mujer acusada de faltar al honor de la familia (incluso si ha sido violada) es abandonar su casa para vivir en prisión. Al menos, eso sucede en Pakistán. 
realidad sociológica en la que el hombre árabe aspira a casarse con «una joven virgen sin experiencia, simple, e ignorante como una niña, una gatita ciega» (El Saadawi, 2017, p. 195).

La ceremonia describe, con claridad, la configuración de una sociedad arcaica en donde el matrimonio se considera «más como un negocio o alianza entre dos familias, que como la unión de dos individuos» (Ruíz de Almodóvar y Sel, 1988, p. 235). Así, «la familia, como en la época preislámica, pasó a ser la encargada de organizar los arreglos matrimoniales y elegirle marido a la joven, ignorando la capacidad legal de la mujer, estipulada en el Corán y en el Derecho, para contratar su propio matrimonio» (Ruíz de Almodóvar y Sel, 1988, p. 236).

Esto se muestra bien en la trama, pues es el padre quien acuerda el matrimonio, sin que la novia conozca a su futuro marido, hasta su boda en la mezquita, para darle un aspecto de sacralidad, aunque el Corán establece que debe dar su consentimiento.

Tras el enlace, el padre recibe la dote en dinero, que no deja de ser casi una transacción comercial en la que parece que el marido ha comprado a la esposa ((Ruíz de Almodóvar y Sel, 1988, p. 238) ${ }^{38}$. Los hombres por un lado, y las mujeres por otro, como es costumbre, bailan y cantan, celebrando la boda. Pero aquí, se pone en evidencia que para Noojom es solo un juego (y cuando se aburre se marcha con sus amigas) que acepta, al principio, ilusionada al verse deslumbrada por lo que ha visto en la celebración de otra boda, no es consciente de las consecuencias ni obligaciones que eso trae consigo.

Después de todo, Noojom no deja de ser una niña con una infancia arrebatada (en plena celebración de su boda se va con unas niñas de su edad de las que se ha hecho amiga o vende su anillo de boda para comprarse una muñeca); y que no es consciente de lo que implica ser una mujer casada, inocente e ignorante de la realidad a la que se verá forzada a vivir. Se le suprime su niñez de forma salvaje y repentina, no solo eso, sino también la posibilidad de poder educarse y madurar como mujer, reduciendo su labor a ser mera guardiana del hogar (Kayaní y Zein, 2002, p. 41). Su marido, de una tribu pudiente de un pueblo fuera de la ciudad, la lleva a otro universo. $Y$ aquello que se espera de ella es trabajar y tener hijos (cuando ya tenga la edad), ser sumisa y obedecer. Pero no es lo mismo para una niña que para una mujer hecha. En la misma noche de bodas, la niña se convierte en mujer a la fuerza (en otras palabras, es violada ${ }^{39}$ ), mostrándose el cruel destino que la aguarda con un marido insensible y la incomprensión de una suegra que confía en que cumpla

38 «A pesar de la reforma [del Corán], la dote siguió entregándose a la familia, como en la época preislámica, y esta tenía libertad para gastarla en lo que quisiera».

${ }^{39}$ En este caso, es muy duro, ya que la protagonista es una niña aferrada a su muñeca. Pero es algo bastante más común de lo que parece el maltrato y violación domésticos (incluidos países desarrollados). 
con sus deberes de servidumbre (acarrear agua, trabajar en el campo, cocinar, limpiar, yacer con su marido, etc.).

A partir de ahí, la actitud callada, desesperada y reservada de Noojom, muestra el trauma y la pérdida de la alegría e inocencia iniciales. De hecho, intentará, sin lograrlo, suicidarse, otro tema de interés que muestra, en este caso, la desesperación de la niña y que simboliza la decisión irrevocable de tantas otras mujeres que no pueden soportar esta descarnada realidad (Kayaní y Zein, 2002, pp. 261-267).

Pero también muestra la mentalidad arcaica de su marido y su suegra (Ruíz de Almodóvar y Sel, 1988, p. 239) ${ }^{40}$ quienes creen actuar bien y piensan que está "malcriada», sin darse cuenta de que es solo una niña que ha pasado de jugar con muñecas a tener que actuar como una mujer adulta. $Y$ deciden corregirla mediante el castigo o el encierro (Kayani y Zein, 2002, p. 236) ${ }^{41}$. Puesto que se considera que «casándose con una niña que aún no había tenido tiempo de aprender nada de la vida, le resultaba más fácil modelarla según sus gustos y someterla a sus más mínimos caprichos» (Ruíz de Almodóvar y Sel, 1988, p. 237). Claro que esa situación forzada por la resistencia de Noojom a plegarse despierta otra situación: la deshonra que puede provocar en la familia el que se sepa que no quiere cumplir con sus tareas. Y cuando su marido la lleva de regreso con su familia, la misma que tanto la quiere, para que hablen con ella, su padre le expresa que no pueden hacer nada porque es su marido y debe cambiar de actitud y aceptar la situación. Por eso, cuando el marido y el padre son encausados por el juez, no entienden qué crimen han cometido, al haber sido fieles a la tradición.

La película es un amargo y duro alegato en favor de la infancia (también de los niños explotados, caso del hermano), centrándose, sobre todo, en las féminas desvalidas que se ven presas de la tradición y del honor, de la brutalidad y las contradicciones de una sociedad con un fuerte carácter tribal, y donde hasta la propia ley carece de facultades para ayudarlas. Pero donde se deja claro que «la pobreza es el principal factor que conduce a este tipo de prácticas» (Kayani y Zein, 2002, p. 73).

El padre no actúa con maldad o a sabiendas de lo que le ocurrirá a su hija, sino porque cree que así tendrá un futuro honesto que, de otro modo, ante la falta de expectativas, sería más incierto. Pues teme que su querida hija pierda el honor antes de tiempo, tras la mala experiencia de su hermana violada. La importancia de la virginidad y el oprobio de perderla son un elemento central que estigmatiza tanto a la mujer, claro está, como a la propia familia (Kayani y Zein, 2002, pp. 109-126; El Saadawi, 2017, p. 108).

40 «La suegra, bajo cuyo poder directo queda ella, espera que sea obediente, retraída y la ayude, si las necesidades económicas lo exigen, en las tareas domésticas, lo cual la convierte en su sirvienta, dispuesta en todo momento a satisfacer sus deseos».

${ }^{41}$ Debido a que se considera que el marido tiene «derecho de corrección». 
Como dice el padre de Noojom, desde el punto de vista masculino, «tener una hija es una maldición". De hecho, se culpa a la misma madre, como si fuese responsabilidad suya. Y mientras se considera que traer un hijo es una bendición, el traer nuevas féminas, más bien lo contrario (El Saadawi, 2017, p. 85).

La trama no solo nos desvela un caso bastante impactante, sino que también describe, ante todo, las viejas mentalidades, de manera matizada, de la que son presos todos los protagonistas y sin caer en maniqueísmos (pues el padre casa a Noojom por pura desesperación, al no encontrar un trabajo con el que sostener a su familia), enfrentados a los nuevos valores sociales de un modo didáctico y claro, que invita a velar por estas niñas-mujeres, sin enfrentarse al islam, sino a buscar la manera de encontrar un equilibrio entre el Estado y el islam, entre una jurisdicción proteccionista con las mujeres, sin faltar al respeto a la religión (El Saadawi, 2017, p. 395). De hecho, hay que pensar que en el momento del divorcio «el Corán insiste en que la petición (...) debe formularse fuera del periodo menstrual» (Fernández Guerrero, 2011, p. 282).

El problema es cuando la esposa ni tan siquiera todavía lo tiene porque es una niña. Y aquí es donde se enfatiza mucho la cruda realidad de Noojom.

10 años y divorciada se convierte, en consecuencia, en una hábil y aguda denuncia de los arcaísmos y tradicionalismos (producto de la ignorancia, frente a la educación y la conciencia). Su gran mérito reside en su mensaje aleccionador y esperanzador. $Y$ en mostrar la enorme felicidad que provoca en Noojom el poder ir a la escuela como una niña normal, rompiendo y atacando de frente, así, el prejuicio que se sostiene en diversos ámbitos de que «la inteligencia deforma el carácter femenino de las chicas» (El Saadawi, 2017, p. 215). Al revés, es como realmente se forma.

\subsection{Egipto: El Cairo 678 (2010), de Mohamed Diab ${ }^{42}$}

Un tema tremendamente preocupante en Egipto ha sido y sigue siendo el acoso sexual. Se trata de una sociedad moderna (más abierta y moderada que la de Arabía Saudí), pionera incluso en el cambio social y en la participación de la mujer en la vida pública (Azaola Piazza, 2004, pp. 161-174) ${ }^{43}$, pero una encuesta de la ONU mostraba que el 99 \% de las mujeres egipcias, en 2003, había sido acosada en la calle (González, 2017). El 75 \% de ellas llevaba el hiyab, lo que en términos religiosos es lo adecuado (Al Aswany, 2011, p. 112). Tal es la situación que, incluso, se han

42 Egipto, 2010. Título original: 678. Productora: New Century Productions. Dirección: Mohamed Diab. Guión: Mohamed Diab. Música: Hani Adel. Fotografía: Ahmed Gabr. Intérpretes: Boshra, Nelly Karim, Maged El Kedwany, Nahed El Sebaï, Bassem Samra, Ahmad El-Fishawi, Omar El Saeed, Sawsan Badr, Yara Goubran y Ibrahim Salah. Duración: 100 min.

${ }^{43}$ Si bien, ha retrocedido en los últimos años. 
hecho apuestas necesarias y originales, orientadas precisamente a la educación y sensibilización de la sociedad sobre este tema.

Por ejemplo, Deena Mohamed, una estudiante de diseño gráfico egipcia, ideó un cómic protagonizado por una mujer con velo, Qahera (victoriosa), una superheroína que se encarga de defender a las mujeres, y pone en su lugar a hombres y mujeres. El hecho de que lleve velo rompe el tópico de mujer sumisa y disciplinada, e impide, así mismo, su rechazo directo por los más ultraortoxodos. Pues su principal misión no es otra que denunciar tanto la misoginia como la lacra del acoso sexual que se da en la sociedad y que tan poco hacen las autoridades para combatirlo (Peralta Ferreyra, 2015, p. 82). Si bien, hay otros ejemplos igual de interesantes de otras dibujantes que difunden sus trabajos a través de Internet (Jurados, 2018). Y aunque el intelectual egipcio Al Aswany reflexiona sobre cómo ha sido posible que una sociedad egipcia donde antes era aceptado que las mujeres pudiesen bañarse en público y mostrar parte de su piel desnuda o, bien, ir en minifalda, haya derivado en esto. Considera que esta cosificación de la mujer es impropia de la cultura del país y que ha sido, desgraciadamente, importada de sociedades beduinas. Reclamaba recuperar ese respeto que siempre se ha tenido por las mujeres (que no dejan de ser sus madres, hijas o esposas), aunque, por desgracia, la lacra continúa y, como vemos en el filme, tampoco el Gobierno ha hecho mucho, en el marco de una idiosincrasia social, por combatir tales comportamientos eficazmente (Al Aswany, 2011, pp. 113-115).

Inspirada en la experiencia real de tres mujeres egipcias, Nelly (Nahed El Sebai), Fayza (Boushra) y Seba (Nelly Karim), El Cairo 678 nos cuenta sus traumáticas experiencias. Fayza es una mujer de extracción humilde que trabaja como funcionaria de bajo nivel. Viste de forma tradicional y discreta. Cada día acude a las oficinas donde desempeña su labor dependiendo del trasporte público, más concretamente debe coger el autobús 678 (del que cobra título el filme). Pero lo que parece un simple acto cotidiano para ella es terrible, ya que es acosada constantemente en el abarrotado trasporte. $Y$ aunque intenta coger un taxi, resulta caro. Todo esto afecta profundamente a su vida, no solo a nivel psicológico, sino vital, porque se enfría su relación con su marido, Adel, oficial de policía, y condiciona su trabajo, porque llega tarde y le reducen el sueldo (y eso lleva a que no pueda pagar las cuotas del colegio de sus hijos). Fayza debe vivir esta situación de indefensión cada día, necesitan cada lira para vivir, en una espiral de acoso que ya no puede soportar más, hasta que decide actuar y defenderse.

El otro caso es el de Seba. Esta es una mujer independiente (regenta su propio negocio) y perteneciente a un barrio pudiente de la ciudad, nada que ver con Fayza. Su marido, Sherif, es médico y un gran aficionado al fútbol. Cierto día acuden a ver un encuentro, deporte muy popular en Egipto. Pero a la salida, celebrando el éxito del partido, entre la multitud, Seba, que está embarazada, es arrastrada y rodeada por varios hombres que la manosean, mientras otros 
retienen a su marido. El jolgorio y celebración futbolística se convierte en una pesadilla para ella.

Sin embargo, como consecuencia de lo ocurrido, su marido, lejos de arroparla, se aleja de ella, durmiendo en el hospital y sintiendo una profunda vergüenza, como si ella fuera la responsable de lo ocurrido, y preocupándose tan solo de su propia humillación. Y cuando ella decide dar el paso y denunciar lo ocurrido, su madre se lo impide por el oprobio que puede caer sobre su familia si el hecho se hace público. Tanta presión y angustia le provocarán un aborto.

Esta terrible circunstancia y la incomprensión inicial de Sherif harán que rompa su matrimonio (él se arrepiente e intenta recuperarla, pero es muy tarde). Su terrible experiencia la hace convertirse en una activista contra el acoso impartiendo clases gratuitas a las mujeres que lo requieran, exhortándolas a la denuncia y a la defensa de su dignidad. Y ahí es donde conoce a la pobre Fayza, primero, y después a Nelly.

La tercera mujer es Nelly, una humorista aficionada. Es, así mismo, teleoperadora de profesión y de vivo carácter. Sin embargo, hasta este trabajo se torna difícil para una mujer, ya que recibe ofertas para citarse con ella. $Y$ no encuentra ninguna comprensión por parte de su jefe al que no le gusta su actitud por colgar al cliente abruptamente. Un buen día, tras dejar a su novio Omar, e ir a cruzar la calle, un hombre la agarra y la tira al suelo. La mira y, como si fuese una broma, le lanza un beso. Nelly, enfurecida, le persigue y lo alcanza, y consigue que sea detenido.

Si ya el suceso es grave, la dejación de las autoridades es aún más humillante.

El policía que se ocupa de ella no quiere incluir en el informe que ha sufrido acoso sexual, solo es una agresión física. Para el policía es más grave el ataque que el acoso, al considerar que esto solo puede provocar un escándalo (y manchar así la reputación de Nelly), revelando una falta total de sensibilidad por parte de las mismas autoridades con tales comportamientos. $Y$ al insistir, el policía decide negarse a tramitar la denuncia (para hacerlo deben ir a la comisaría principal y llevar ellos mismos al agresor para realizar los trámites). Todo ello es muy revelador de la indefensión femenina y la actitud pasiva de las fuerzas del orden. Pero que también tiene mucho que ver con una sociedad machista en términos laborales, ante la ausencia de agentes femeninas que, por ejemplo, puedan atender y sensibilizarse con tales hechos (Fernández Ruiz-Gálvez, 2017, p. 285) ${ }^{44}$.

La denuncia trasciende y Nelly es entrevistada en un programa de televisión al ser la única mujer que ha denunciado acoso sexual en todo Egipto. Pero, aunque parece ser una primera brecha en una idiosincrasia social callada y negada, la madre le pide a Nelly que retire la denuncia. Nadie la apoya, salvo Omar, pero incluso

${ }^{44}$ De ahí la necesidad de un empoderamiento femenino, ya que «para combatir la violencia sobre la mujer, [se debería] reestructurar la sociedad de tal modo que mujeres y varones compartan el poder equitativamente». 
este está atrapado por los imperativos familiares, el estigma social ${ }^{45}$, que le exigen a Nelly no seguir con la causa. Hay rumores que afirman que este caso no es sino una perversa conspiración para ensuciar la imagen de Egipto.

Finalmente, Fayza, atenazada por el desvelo del acoso, decide tomarse la justicia por su mano y acuchillar a sus agresores. La policía, ahora sí, interviene tirando del hilo y buscando la manera de detener al múltiple agresor, no porque quieran acabar con el acoso, sino por el pánico social generado entre los hombres. Y aquí la trama gira y nos desvela, así mismo, la personalidad y la situación de los propios agredidos, hombres jóvenes (Nasr o Hamdi), sin fortuna o trabajo, y que por ese motivo no pueden aspirar a casarse; hombres casados que buscan, en estos contactos fortuitos, un desahogo debido a sus matrimonios frustrados (Adel) o por encontrar en ello placer (Maher). Y que, después de todo, se ven reforzados por la aquiescencia e idiosincrasia sociales machistas y tan tradicionales.

El largometraje no solo se ocupa de presentar tres casos bien distintos de mujeres que configuran una realidad entrelazada, de caracteres y extracciones sociales diferentes, como arquetipos de las mujeres egipcias, que son acosadas y agredidas, sino su indefensión e incomprensión social y la retrógrada mentalidad imperante, en la que se estigmatiza a la propia víctima.

También, en su virtud, nos perfila a los agresores, hombres corrientes, con sus vidas y familias, que acosan empujados por la necesidad sexual. Aunque se les compadece, no se les justifica, sino que, precisamente, la historia tiene la hondura suficiente para ofrecernos estas dos caras de la misma moneda, explicando el problema, radiografiando las preocupaciones femeninas y las causas que provocan el acoso, sin justificarlo, claro está, así como el modo en que tan fría y descarnadamente la sociedad y sus valores impiden enfrentarse de raíz al problema, condenando al acosador, amparando a la víctima y acabando con los convencionalismos atenazados por un puritanismo que genera y ampara esta clase de comportamientos tan lesivos.

Parece que solo el miedo social cuando se hace público (ante la amenaza de ser agredido), hace reaccionar a la sociedad (a los hombres) y a las autoridades. Pero, incluso, estas últimas lo ven un problema menor y, cuando las tres mujeres son detenidas, se les hace una mera advertencia, sin encausarlas. De forma directa y amarga, también desvela la fragilidad de los propios hombres que no solo no saben escuchar y apoyar a sus mujeres, sino que no se dan cuenta de lo importantes que son hasta que es demasiado tarde, sufriendo las consecuencias.

La historia deriva, así, en un alegato duro y frontal a una realidad tan áspera como tremenda para tantos millones de mujeres que se ven indefensas, ya sea por

45 Quien ha tenido que entrar a trabajar en un banco, renunciando a su futuro como humorista, para que los padres de Nelly le acepten como futuro yerno (pues no lo harían con un hombre sin trabajo). 
la incomprensión de sus familias, por las autoridades o por la misma sociedad, que las estigmatiza y denigra, porque es un tema tabú al que nadie quiere hacer frente. Demuestra, muy bien, el hartazgo de tantas féminas a las que no se las escucha ni se les hace caso. Pero, al mismo tiempo, hace un retrato que permite observar el modo en que todo esto repercute a nivel individual y social en todos ellos, porque también afecta a las familias y, cómo no, a hombres (maridos, novios, padres y niños) directamente con sus comportamientos, en una espiral terrible en la que, por supuesto, ellos son responsables (salvo notables excepciones, como el personaje de Omar), en unos casos por actuar de forma tan atroz, en otros por no querer escucharlas o los que se resignan a ello sin apoyarlas o comprometerse en pugnar contra esta lacra.

Solo lo hacen cuando se sienten afectados ellos mismos o tardíamente, como el inspector de policía, debido a la suerte de su propia familia.

Aunque tampoco obvia las discrepancias entre las propias mujeres, quienes acabarán reprochándose ser responsables de lo sucedido, en un enfrentamiento que, claramente, refleja ese choque de mentalidades, entre una tradicional y otra más moderna, de la sociedad egipcia. Sin embargo, en la trama prima el carácter sensibilizador que busca apelar a la conciencia para cambiar tales indecentes comportamientos y reivindicar su importancia y gravedad, frente a la incapacidad de la sociedad de enfrentarse a tal drama social. Y, aun así, todavía es un problema.

En 2014, cuatro años después del rodaje de este filme, fue cuando se aprobó una normativa contra el acoso sexual tipificándolo como delito, teniendo que endurecerla tres años después, porque no se había conseguido nada relevante (de hecho, se ha considerado a El Cairo como la ciudad más peligrosa del mundo para las mujeres). A pesar de tales medidas, la realidad amarga supera a la ficción. Puesto que, a pesar del final esperanzador del filme, recientemente, la activista por los derechos humanos, Amal Fathy, acabó siendo encarcelada por denunciar el acoso en Facebook, y condenada a dos años de cárcel, así mismo, por "difundir informaciones falsas» y "minar la seguridad nacional», además de por actividades terroristas (González, 2018). Muy diferente suerte corre el personaje de Nelly. 


\section{Cuadro síntesis ideas principales}

\begin{tabular}{|c|c|c|c|c|}
\hline PELÍ́CULA (9) & $\begin{array}{c}\text { PAÍS DE } \\
\text { PRODUCCIÓN }\end{array}$ & MARCO HISTÓRICO & $\begin{array}{l}\text { SITUACIÓN DE } \\
\text { LA MUJER }\end{array}$ & TEMÁTICAS \\
\hline $\begin{array}{l}\text { ¿Y ahora } \\
\text { adónde vamos? } \\
\text { (2011), de } \\
\text { Nadine Labaki. }\end{array}$ & Líbano. & $\begin{array}{l}\text { Líbano a inicios del } \\
\text { siglo } x x I .\end{array}$ & $\begin{array}{l}\text { - Víctimas } \\
\text { de guerras } \\
\text { intestinas. }\end{array}$ & $\begin{array}{l}\text { - Conflictividad } \\
\text { entre musulmanes- } \\
\text { cristianos. } \\
\text { - Prejuicios } \\
\text { religiosos. } \\
\text { - Alteridad y } \\
\text { feminismo } \\
\text { como base de } \\
\text { la resolución de } \\
\text { conflictos. }\end{array}$ \\
\hline $\begin{array}{l}\text { Los limoneros } \\
\text { (2008), de Eran } \\
\text { Riklis. }\end{array}$ & Israel. & $\begin{array}{l}\text { Cisjordania contexto } \\
\text { reciente. }\end{array}$ & $\begin{array}{l}\text { - Víctimas de } \\
\text { un conflicto } \\
\text { irresuelto. }\end{array}$ & $\begin{array}{l}\text { - Conflicto israelí- } \\
\text { palestino y los } \\
\text { trastornos en la } \\
\text { sociedad civil. } \\
\text { - La injusticia israelí. } \\
\text { - Miedos y prejuicios } \\
\text { sociales. } \\
\text { - La alteridad } \\
\text { femenina. } \\
\text { - Sufrimiento y } \\
\text { resiliencia femenina. }\end{array}$ \\
\hline $\begin{array}{l}\text { Buda estalló } \\
\text { por vergüenza } \\
\text { (2007), de Hana } \\
\text { Makhmalbaf. }\end{array}$ & Irán. & $\begin{array}{l}\text { Afganistán tras el fin } \\
\text { del régimen talibán. }\end{array}$ & $\begin{array}{l}\text { - Víctimas de } \\
\text { la indefensión } \\
\text { frente al } \\
\text { integrismo y la } \\
\text { miseria social. }\end{array}$ & $\begin{array}{l}\text { - La importancia de } \\
\text { la educación. } \\
\text { - Intransigencia } \\
\text { talibán. } \\
\text { - Situación de } \\
\text { vulnerabilidad de la } \\
\text { infancia. } \\
\text { - (In)visibilidad } \\
\text { femenina. }\end{array}$ \\
\hline $\begin{array}{l}\text { La piedra de } \\
\text { la paciencia } \\
\text { (2012), de Atiq } \\
\text { Rahimi. }\end{array}$ & Afganistán. & $\begin{array}{l}\text { Afganistán, tiempo } \\
\text { indefinido. }\end{array}$ & $\begin{array}{l}\text { - Víctimas frente } \\
\text { a la realidad de } \\
\text { la guerra y el } \\
\text { tradicionalismo. }\end{array}$ & $\begin{array}{l}\text { - Se reivindica la } \\
\text { rica y compleja } \\
\text { psicología femenina. } \\
\text { - Situación de } \\
\text { vulnerabilidad de } \\
\text { la mujer ante los } \\
\text { conflictos armados. } \\
\text { - Resiliencia femenina. }\end{array}$ \\
\hline
\end{tabular}




\begin{tabular}{|c|c|c|c|c|}
\hline PELÍCULA (9) & $\begin{array}{c}\text { PAÍS DE } \\
\text { PRODUCCIÓN }\end{array}$ & MARCO HISTÓRICO & $\begin{array}{l}\text { SITUACIÓN DE } \\
\text { LA MUJER }\end{array}$ & TEMÁTICAS \\
\hline $\begin{array}{l}\text { La bicicleta } \\
\text { verde (2012), } \\
\text { de Haifaa Al } \\
\text { Mansour. }\end{array}$ & $\begin{array}{l}\text { Arabía Saudí y } \\
\text { Alemania. }\end{array}$ & Arabia Saudí actual. & $\begin{array}{l}\text { - Víctimas de } \\
\text { un sistema } \\
\text { ideológico } \\
\text { retrógrado y } \\
\text { machista. }\end{array}$ & $\begin{array}{l}\text { - Educación } \\
\text { femenina como base } \\
\text { de su sometimiento } \\
\text { social. } \\
\text { - Indefensión de la } \\
\text { mujer. } \\
\text { - Tradicionalismo } \\
\text { versus modernidad. } \\
\text { - Papel renovador } \\
\text { de la infancia para } \\
\text { un cambio de } \\
\text { mentalidad. }\end{array}$ \\
\hline $\begin{array}{l}\text { Persépolis } \\
\text { (2007), de } \\
\text { Marjane Satrapi } \\
\text { y Vincent } \\
\text { Paronnaud. }\end{array}$ & Francia. & $\begin{array}{l}\text { Irán antes y después } \\
\text { de la revolución } \\
\text { islámica. }\end{array}$ & $\begin{array}{l}\text { - Víctimas de } \\
\text { un sistema } \\
\text { ideológico } \\
\text { retrógrado y } \\
\text { machista. }\end{array}$ & $\begin{array}{l}\text { - Pérdida de } \\
\text { derechos y } \\
\text { libertades sociales. } \\
\text { - Control social de } \\
\text { las costumbres. } \\
\text { - Sometimiento de } \\
\text { la mujer. }\end{array}$ \\
\hline $\begin{array}{l}\text { La fuente de } \\
\text { las mujeres } \\
\text { (2011), de Radu } \\
\text { Mihaileanu. }\end{array}$ & $\begin{array}{l}\text { Bélgica, Italia y } \\
\text { Francia. }\end{array}$ & $\begin{array}{l}\text { Localidad } \\
\text { musulmana } \\
\text { (inspirado en un } \\
\text { suceso en Turquía). }\end{array}$ & $\begin{array}{l}\text { - Víctimas del } \\
\text { machismo. }\end{array}$ & $\begin{array}{l}\text { - Situación de } \\
\text { la mujer en una } \\
\text { cultura machista. } \\
\text { - Falta de evolución } \\
\text { y cambio en el rol } \\
\text { masculino. } \\
\text { - Resiliencia } \\
\text { y superación } \\
\text { femenina. }\end{array}$ \\
\hline
\end{tabular}

\begin{tabular}{|c|c|c|c|c|}
\hline $\begin{array}{l}10 \text { años y } \\
\text { divorciada } \\
\text { (2014), de } \\
\text { Khadija Al- } \\
\text { Salami. }\end{array}$ & Yemen. & $\begin{array}{l}\text { Yemen } \\
\text { contemporánea } \\
\text { antes de la guerra } \\
\text { civil. }\end{array}$ & $\begin{array}{l}\text { - Víctimas de } \\
\text { las costumbres } \\
\text { e idiosincrasias } \\
\text { sociales. }\end{array}$ & $\begin{array}{l}\text { - Tradicionalismo, } \\
\text { pobreza y } \\
\text { marginación social. } \\
\text { - Indefensión de la } \\
\text { infancia. } \\
\text { - La lacra de los } \\
\text { matrimonios } \\
\text { infantiles. }\end{array}$ \\
\hline $\begin{array}{l}\text { El Cairo } 678 \\
\text { (2010), de } \\
\text { Mohamed Diab. }\end{array}$ & Egipto. & $\begin{array}{l}\text { Egipto actual antes } \\
\text { de la primavera } \\
\text { árabe }\end{array}$ & $\begin{array}{l}\text { - Víctimas del } \\
\text { acoso social. }\end{array}$ & $\begin{array}{l}\text { - Situación de } \\
\text { indefensión de las } \\
\text { mujeres ante el } \\
\text { acoso. } \\
\text { - Desinterés de las } \\
\text { autoridades por } \\
\text { atajar el problema. } \\
\text { - Graves traumas } \\
\text { familiares. }\end{array}$ \\
\hline
\end{tabular}




\section{A MODO DE CONCLUSIÓN}

A lo largo de este artículo se han ido presentando diferentes películas ambientadas en escenarios tan diversos como Líbano, Palestina, Afganistán, Arabía Saudí, Irán, Turquía, Yemen o Egipto (en el marco de Oriente Medio y Asia) para que los puntos de vista y las sensibilidades que se desvelan sobre la mujer musulmana sean lo más variados posible. Pero no debemos verlos solo como vehículos que codifican realidades concretas.

De hecho, como se ha evidenciado en algunos de estos largometrajes, se esgrimen mensajes universales de concienciación y reflexión sobre la situación femenina sin ubicarlos en un lugar o contexto concreto (salvo por la nacionalidad de las producciones), como en La fuente de las mujeres (2011) y La piedra de la paciencia (2012).

En otros casos son, sin duda, realizaciones específicas de contextos marcados por la violencia como el conflicto libanés, palestino o afgano, en ¿Ahora adónde vamos? (2011), Los limoneros (2008) y Buda estalló por vergüenza (2007), pero muy reveladores de sus padecimientos en cualquier contexto similar o parecido que se pueda dar o haya podido darse. La cultura tribal también va a ser otro rasgo que interesa y mucho mostrar, en su lado más arcaizante y amargo, sobre el matrimonio infantil (que ocurre con frecuencia en Yemen, pero también en otros muchos países), aunque no sea en la sociedad donde se dan o se producen dichos casos, como se ilustra en 10 años y divorciada (2014). Y tampoco se pueden ignorar los problemas que se observan en sociedades más desarrolladas del mundo árabe o persa incluso, donde la mujer ha adquirido mayores derechos sociales y laborales, la terrible lacra del acoso sexual, como se demuestra en El Cairo 678 (2010) o su sometimiento a leyes discriminatorias que las tratan como si fuesen menores de edad o incapaces de pensar y actuar por ellas mismas, como se observa en La bicicleta verde (2012) y en Persépolis (2007).

Realidades y ficciones, como se han ido analizando, se confunden para mostrarnos un cuadro complejo de una condición femenina que no resulta fácil sobrellevar, al revés, es duro y terrible, porque todavía viene marcado por el efecto de la violencia, de su propia invisibilidad social o del peso que cobran las tradiciones a la hora de ser tratadas en igualdad respecto a sus homólogos masculinos. Pero también estos retratos fílmicos podrían ser más crudos y desangelados, porque las problemáticas que se dan suelen ser mucho más desgarradoras en el plano real. En algunos casos, se suaviza para que su mensaje sea más efectivo y llegue a más amplios sectores de la sociedad a la que va dirigida. El cine, aunque realista y directo, también sostiene limitaciones a la hora de ofrecer una radiografía más completa de la sociedad que retrata, pero, en estos casos, se limita a abordar la conciencia social. Sobre todo, porque su intención, como se ha indicado, no es de plantear una revolución feminista que la confronta al sistema, sino de actuar de catalizador para 
inducir a que se vayan cambiando las mentalidades, dando paso a un reconocible empoderamiento de la mujer, sin enfrentarse al islam.

El control que ostentan de los preceptos religiosos islámicos los integristas y los sectores más conservadores redunda en esta situación de subordinación femenina. Enfrentarse directamente a ellos es peligroso. Por eso los realizadores y realizadoras han mostrado ser cuidadosos para no provocar un rechazo frontal de su discurso, sino que encaran con sutileza el proceso de transformación social al que se insta directa o indirectamente o subliminal, respetando el islam, y abogando por un cambio de cultura dominante. Mayormente, se interpela y llama la atención a ambos sectores con un propósito sensibilizador. Por un lado, se muestran los padecimientos de las mujeres, víctimas directas o indirectas de conflictos, viendo como sus seres queridos, hijos, hermanos o esposos fallecen, o como ellas deben padecer los efectos de la misma violencia y de la indefensión. Y, por otro, para que la comunidad musulmana no considere que tales planteamientos sean antiislámicos, no lo son, al contrario, se revelan muy cuidosos con el tratamiento de la doctrina, reivindicando únicamente las diferentes facetas de la dignidad femenina y afianzando su identidad.

El hecho de que varios de estos filmes sean protagonizados por niñas, que padecen y sufren en sus propias carnes las lacras del machismo o el integrismo (Buda estalló por vergüenza (2007), 10 años y divorciada (2014) y La bicicleta verde (2012)), acerca a un punto de vista donde su presunta inocencia se ve estigmatizada por los valores sociales y educación recibidos, indicativo de lo que se pretende, como es ir cambiando la sociedad desde abajo. Por eso, en todas ellas, se remarca la relevancia del factor educativo para liberar a la mujer de esta subordinación o situación de indefensión. Y, por supuesto, la educación no deja de ser un pilar para que tomen una mayor conciencia de ellas mismas.

Del mismo modo, se facilitan retratos de mujeres o niñas que sienten, piensan, aman, sufren y padecen, que tienen aspiraciones y una psicología más rica y profunda de lo que se las adjudica en el mundo masculino. Su marcado protagonismo en cada uno de los filmes tratados recalca, precisamente, este lado emocional. No son solo posesiones o seres pasivos que han de soportar la carga de la familia con resignación, el dolor, la pérdida o la humillación, sino que lo hacen sufrimiendo, aunque sus aspiraciones sean otras y también ellas pretendan alcanzar vidas plenas y satisfactorias.

Además, también se aborda críticamente que no solo la familia o la sociedad, sino las mismas mujeres sean las que defienden y garantizan la pervivencia de sus propias cadenas, tal y como se reflejan en filmes como La fuente de las mujeres (2011), La bicicleta verde (2012), 10 años y divorciada (2014), o El Cairo 678 (2010).

En suma, aunque esta investigación es solo una muestra genérica de algunas de las muchas realizaciones que se han llevado a cabo sobre la mujer musulmana, denota, a través de las películas elegidas, la activa y presente lucha social que se está 
llevando a cabo de la visibilización de sus padecimientos e identidad. No solo como meros alegatos que denuncian su maltrato o que sacan a relucir sus injustos sufrimientos, víctimas de conflictos o de tradicionalismo arcaicos, sino también como un vehículo de expresión educativa que ayude a un cambio de percepción en el mundo islámico. Y vea en las mujeres no solo un ideal constreñido a los fundamentos religiosos, sino a seres de carne y hueso, con voluntad y sentimientos propios, seres pensantes que no solo reivindican respeto y bienestar, sino también que se reconozca su valor individual.

\section{REFERENCIAS BIBLIOGRÁFICAS}

https://www.filmaffinity.com/es/film843847.html [Consultado el 2-1-2018].

https://www.elespectador.com/impreso/articuloimpreso138753-mujeres-huelgasexual [Consultado el 31-5-2018].

https://web.archive.org/web/20110515225133/http://www.makhmalbaf.com/ persons.php? $\mathrm{p}=2$ [Consultado el 15-12-2018].

https://web.archive.org/web/20110719163223/http://makhmalbaf.com/persons. php? $\mathrm{p}=1$ [Consultada el 15-12-2018].

https://www.unicef.org/spanish/sowc/archive/SPANISH/Estado\%20Mundial\%20 de\%20la\%20Infancia\%202000.pdf [consultado el 28-12-2018].

http://hdr.undp.org/sites/default/files/hdr_2001_es.pdf [consultado el 28-122018].

Abumalham, M. (1999). La percepción interior y exterior de la imagen de la mujer musulmana. En VV. AA., El Islam: presente y futuro (pp. 139-182). Madrid: Ministerio de Defensa.

Adelkhah, F. (1996). La revolución bajo el velo. Mujer iraní y régimen islamista. Barcelona: Edicions Bellaterra.

Aguirre, M. (2015). Bombas sobre Yemen. El Viejo topo, núm. 328, pp. 32-39.

Aguirre Romero, J. M. a (2014). La bicicleta verde (Wadjda, 2012): un futuro sobre ruedas. Espéculo. Revista de estudios literarios, núm. 53, julio-diciembre, pp. 120-158. 
Al Aswany, A. (2011). Egipto: las claves de una revolución inevitable. Barcelona: Galaxia Gutenberg.

Álvaro Navarro, M. (2019, 22 de julio). Desayunos que combaten el matrimonio infantil en Yemen. El País.

Apellaniz, A. (2017). La insurgencia afgana. En J. I. Castien Maestro y L. Herruzo Madrid (eds.)., Afganistán. Pasado y perspectivas de futuro (pp. 233-285). Bilbao: El Viejo Topo.

Arabaci, S. (2018). El movimiento feminista en Turquía y las nuevas estrategias de resistencia. Pensamiento al margen. Revista digital, núm. 8, pp. 90-109. http:// www.pensamientoalmargen.com.

Armanian, N. y Zein, M. (2012). Irán. La revolución constante. Barcelona: Flor del Viento Ediciones.

Axworthy, M. (2010). Irán. Una historia de Zoroastro hasta hoy. Madrid: Turner.

Ayuso, R. (2013, 22 de junio). Haifaa Al Mansour, rompedora cineasta saudí. El País.

Azaola Piazza, B. (2004). Participación política y social de la mujer egipcia. Feminismo/s, junio, pp. 161-174. https://doi.org/10.14198/fem.2004.3.11.

Badran, M. (2010). El feminismo islámico en marcha. Clepsydra, núm. 9, pp. 69-84.

Badran, M. (2012). Feminismo en el Islam. Madrid: Cátedra.

Barrenetxea, I. (2014). Sufrir y humanizar. El conflicto palestino-israelí en el cine de ficción. Film-Historia Online, 24(2).

Cabello Rodríguez, J. L. (2016). Líbano. En Panorama geopolítico de los conflictos (pp. 133-152), Madrid: Instituto español de estudios estratégicos.

Caferri, F. (2013). El paraíso está a los pies de las mujeres. Barcelona: Paidós.

Carrión, F. (2017, 26 de septiembre). Arabia Saudí permitirá conducir a las mujeres. El Mundo. 
Castien Maestro, J. I. (2017). La dinámica del moderno Afganistán. Un ensayo de interpretación. En Castien Maestro, J. I. y Herruzo Madrid, L. (eds.), Afganistán. Pasado y perspectivas de futuro (pp. 21-114). Bilbao: El Viejo Topo.

Corm, G. (2006). El Líbano Contemporáneo. Historia y sociedad. Barcelona. Edicions Bellaterra.

Cooley, J. K. (2002). Guerras profanas. Afganistán, Estados Unidos y el terrorismo internacional. Madrid: Siglo XXI.

Culla, J. B. (2005). La tierra más disputada. El sionismo, Israel y el conflicto palestino. Madrid: Alianza.

De la Villa Polo, J. (coord.). (2004). Mujeres en la Antigüedad. Madrid: Alianza.

Díaz-Maroto, Z., Carrillo, E. y Puebla, B. (2014). El tratamiento de los olvidados en el cine iraní contemporáneo: Mujer, infancia y minorías étnicas. Cuestiones de género: de la igualdad y la diferencia, 9, pp. 310-337. https://doi.org/10.18002/ cg.v0i9.1035.

El Saadawi, N. (2017). La cara oculta de Eva. La mujer en los países árabes. Madrid: Kailas.

Espinosa, A. (2006). El Reino del Desierto. Arabia Saudí frente a sus contradicciones. Madrid: Aguilar.

Fernández Guerrero, O. (2011). Las mujeres en el Islam: una aproximación. Brocar, 35, pp. 267-286. https://doi.org/10.18172/brocar.1606.

Fernández Ruiz-Gálvez, E. (2017). Educación para la paz desde una perspectiva de género. en Emilia B. y Fernández Ruiz-Gálvez, E. coords. Cien años de discurso femenino sobre la guerra y la paz (pp. 271-296), Valencia: Tirant.

Ferro, M. (1995). Historia contemporánea y cine. Barcelona: Ariel.

Finkelstein, N. G. (2003). Imagen y realidad del conflicto palestino-israelí. Madrid: Akal.

García, R. (2012, 29 de febrero). Soy cineasta gracias a Líbano. Tengo una misión. El País. 
Griffin, M. (2001). El movimiento talibán en Afganistán: cosecha de tempestades. Madrid: Catarata.

Gomà, D. (2011). Historia de Afganistán. Barcelona: Universitat de Barcelona.

González, R. (2017, 18 de enero). Egipto se pone serio con el acoso sexual. El País.

González, R. (2018, 12 de diciembre). Amal Fathy, la egipcia encarcelada por denunciar el acoso sexual. El País.

Higueras, G. (2011, 7 de octubre). El Nobel de la Paz premia el papel de la mujer en el cambio político y social. El País.

Hotait Salas, L. (2013). Ante el dolor: cine de autor en el Líbano, 1970-2006. Tesis doctoral inédita, dirigida por Alberto Elena y Gema Martín Muñoz, Universidad Carlos III.

Jurados, C. (2018). Dibujando contra corriente: llustradores arabo-musulmanas de cómic. Tebeosfera, https://www.tebeosfera.com/documentos/dibujando_ contra_corriente_ilustradoras_arabo-musulmanas_de_comic.html.

Kassir, S. (1994). La guerre du Liban. De la dissension nationale au conflit regional. París-Beirut Karthala: CERMOC.

Kayaní, A. (1998). Entre coronas y turbantes: la mujer en el país de los Ayatolás. Barcelona: Flor del Viento.

Kayaní, Azadé y Zein, M. (2002). Sólo las diosas pasean por el infierno. Barcelona: Flor del Viento.

Khatib, L. (2008). Lebanese Cinema. Imagining the civil war and beyond. Lebanese Cinema. Imagining the civil war and beyond. Londres-Nueva York: I.B. Tauris. https://doi.org/10.5040/9780755696697.

Luján Ramos, M. (2014). Cine e historia en el Líbano desde una perspectiva de género: ¿hacia dónde vamos? Revista Internacional de Pensamiento Político, 9, pp. 149-162.

Mackey, S. (2004). Los saudíes. Barcelona: Paidós. 
Mestre i Mestre, R. coord. (2008). Mujeres, derechos y ciudadanías. Valencia: Tirant lo Blanch.

Magallón, C. (2017). Una voz disidente en la I Guerra Mundial: el Congreso de La Haya y WILPF. En E. Bea y E. Fernández Ruiz-Gálvez (coords.), Cien años de discurso femenino sobre la guerra y la paz (pp. 15-33), Valencia: Tirant, Valencia.

Maquieira, V. (ed.). (2010). Mujeres, globalización y derechos humanos. Madrid: Cátedra.

Martín, J. (2013). La Casa de Saud. Madrid: Catarata.

Medina Gutiérrez, F. (2018). Yemen: un escenario de guerra y de crisis. OASIS: Observatorio de Análisis de los Sistema Internacionales, 27, pp. 91-111. https:// doi.org/10.18601/16577558.n27.06.

Meneses, R. (2017, 5 de noviembre). Alwaleed, un espíritu demasiado libre para Arabia Saudí. El Mundo.

Monge, Y. (2019, 7 de octubre). La guerra interminable de EEUU. El País.

Morales Fajardo, M. E., Mejía López, M. y Galeana Estrada, A. (2017). Terrorismo y Patrimonio Cultural: destrucción y recuperación de los Budas de Bamiyán y del Sitio de Palmira. Contexto, 15, pp. 37-52.

Pappé, I. (2015). La idea de Israel. Una historia de poder y conocimiento. Akal: Madrid.

Pérez Álvarez, M.a Á. y Rebollo Ávalos, M. a J. (2009). El Islam en la vida de la mujer a través de los tiempos. Cauriensia, 4, pp. 227-247.

Peralta Ferreyra, I. (2015). Heroínas islámicas del cómic y la animación en defensa de la educación de la mujer, contra su acoso y la islamofobia. Aularia. Revista digital de comunicación, 1, pp. 81-85. www.aularia.org.

Pozas Pardo, V. S. y Macías, J. (2007). ¿Una extraña coincidencia? En Abre los ojos. Mujeres en sociedades musulmanas (pp. 16-29), Mitos y realidades. Bilbao: Fundeso Euskadi y Diputación Foral de Bizkaia.

Quigley, J. (2005). The case for Palestine. Dirham \& London: Duke University Press. 
Rahimi, A. (2009). La piedra de la paciencia. Madrid: Siruela.

Rashid, A. (2001). Los Talibán. Barcelona, Península.

Rosenstone, R. (2014). La historia en el cine. El cine sobre la historia. Madrid: Rialp.

Ruiz, J. (2012). Líbano, la primavera que no llega. Afkar Ideas, 33, pp. 48-50.

Sand, S. (2005). El siglo XX en la pantalla. Cien años a través del cine. Barcelona: Crítica.

Solar, D. (2002). Sin piedad, sin esperanza. Palestinos e israelíes, la tragedia que no cesa. Granada: Almed.

Sorlin, P. (1996). Cines europeos, sociedades europeas 1939-1990. Barcelona: Paidós.

Ruiz de Almodóvar y Sel, C. (1988). La posición de la mujer musulmana en el matrimonio: su desarrollo social a partir de testimonio coránico. Miscelánea de estudios árabes y hebraicos. Sección Árabe-Islam, 37, pp. 227-239.

Tarrés, S. (2019). En torno al género y las cuestiones corporales femeninas en las doctrinas musulmanas tradicionalistas. Aposta. Revista de Ciencias Sociales, 82, pp. 93-105.

Terrón Caro, T. (2012). La mujer en el Islam. Análisis desde una perspectiva socioeducativa. El futuro del pasado, 3, pp. 237-254.

Van Der Gaag, N. (2005). En lucha: las mujeres y sus derechos. Barcelona: Intermón Oxfam.

Vicente, A. (2008). Entrevista a Eran Riklis. Fotogramas, 1 de octubre, www. fotogramas.es.

Zaccak, H. (1997). Le cinéma Libanais. Beirut: Dar el Machreq.

Zurbano Berenguer, B. (coord.). (2012). Mujeres en Oriente Medio, agentes de desarrollo en un contexto de conflicto. Sevilla: Universidad de Sevilla. 
Página intencionadamente en blanco. 